\title{
Primary production by suspended and benthic microalgae in a turbid estuary: time-scales of variability in San Antonio Bay, Texas
}

\author{
Hugh L. MacIntyre*, John J. Cullen** \\ Marine Science Institute, University of Texas at Austin, Port Aransas, Texas 78373, USA
}

\begin{abstract}
The within-day, between-day and month-to-month variability of light attenuation and microalgal chlorophyll a (chl a) and photosynthetic response was measured in San Antonio Bay, Texas, USA. Waters were shallow $\left(<2 \mathrm{~m}\right.$ ) and turbid (attenuation coefficients of 0.7 to $15.3 \mathrm{~m}^{-1}$ ), yet daily rates of primary production $\left(0.1\right.$ to $\left.2.5 \mathrm{~g} \mathrm{C} \mathrm{m}^{-2} \mathrm{~d}^{-1}\right)$ were comparable to those in much deeper and clearer estuaries. Chl a concentrations in the sediment $\left(459\right.$ to $7837 \mathrm{mg} \mathrm{m}^{-3}$ in the surficial millimeter) were much higher than those in the water column $\left(4\right.$ to $48 \mathrm{mg} \mathrm{m}^{-3}$ ). The benthic assemblages were photosynthetically competent, but daily benthic primary productivity was $10 w 10.00$ to $0.09 \mathrm{~g} \mathrm{C} \mathrm{m}^{-2} \mathrm{~d}^{-1}$; an average of $2 \%$ of productivity in the water column) because of the very low irradiances at the sedimentwater interface. The high rates of production by the suspended microalgae were largely due to high chlorophyll-specific light-saturated rates of photosynthesis. $P_{\mathrm{m}}^{\mathrm{chl}}\left[3.0\right.$ to $\left.24.4 \mathrm{~g} \mathrm{C}(\mathrm{g} \mathrm{chl} \mathrm{a})^{-1} \mathrm{~h}^{-1}\right]$, which were correlated positively with temperature and inversely with the mean irradiance in the water column. The between-day and temperature-independent variation in $P_{\mathrm{m}}^{\mathrm{chl}}$ was also correlated with $F_{v} C h l^{-1}$, an index of the proportion of functional photosystem Il reaction centers. In turn, within-day variability in $F_{\mathrm{v}} \mathrm{Chl}^{-1}$ was inversely correlated with the mean irradiance in the water column in 8 of 10 observations, a pattern consistent with photoinhibition. A depression of $P_{m}^{c h l}$ caused by photoinhibition throughout the water column may therefore be responsible for the inverse trend of $P_{m}^{c h l}$ with mean irradiance in the water column. Short-term (h) variability in suspended chl a and turbidity was high (coefficient of variation $=13$ to $75 \%$ ), but estimates of daily productivity could be predicted with reasonable fidelity (mean error $27 \%$ ) from a single midday determination of chl $a_{\text {, the }}$ thotosynthesis versus irradiance response and the attenuation coefficient, along with daily incident radiation. The predictive power of a single observation was due to coherence in the variation of $c h l a_{1} P_{\mathrm{m}}^{c h l}$ and the attenuation coefficient in the water column: the decrease in mean irradiance caused by resuspension was compensated for by concomitant increases in $P_{\mathrm{m}}^{\mathrm{chl}}$ and suspended chl a. Between-day variability in productivity of 15 to $52 \%$ approached month-to-month differences, so the optimal use of resources in monitoring productivity would be to take single samples daily
\end{abstract}

KEY WORDS: Photosynthesis Photoacclimation Photoinhibition - Benthos - Resuspension - Turbidity Mixing Modeling BZI Estuary

\section{INTRODUCTION}

Primary production by phytoplankton is determined by the availability of light as well as the abundance and photosynthetic competence of the microalgae.

- Present address and correspondence address: College of Marine Studies, University of Delaware, 700 Pilottown Rd, Lewes, Delaware 19958, USA.E-mail: hmac@udel.edu

- Present address: Department of Oceanography, Dalhousie University, Halifax, Nova Scotia, Canada B3H 4J1
Variability in these factors may be due to external forcing (e.g. the daily and seasonal cycles of incident irradiance) or to more interactive changes in biological and physical characteristics of the water column, such as suspended chlorophyll a (chl a) or turbidity. In estuaries, variability in suspended chl a and turbidity occurs on shorter time-scales than the externally imposed daily changes in irradiance or water temperature. The frequency and magnitude of the changes depend on the mechanisms that drive them, and their 
effect on overall rates of primary production depends on the degree to which they influence the co-occurrence of chl $a$ and light.

Turbidity in estuarine waters is determined largely by the concentration of suspended sediments (Cloern 1987). Turbidity can change with tidal frequency, either because of advection of water masses with differing loads of seston (Litaker et al. 1993) or because changes in current velocity cause alternating episodes of suspension and deposition of sediment (Cloern et al. 1989) Resuspension is also caused by wind-driven mixing (Gabrielson \& Lukatelich 1985, Pejrup 1986. Demers et al. 1987. Arfi et al. 1993) and by boat traffic (Anderson 1976, Garrad \& Hey 1987). The dominant short-term frequency with which water clarity varies may therefore be tidal or sub-tidal, depending on the relative influence of tides and winds. This variability is superimposed on the day/night cycle in determining the amount of light to which phytoplankton suspended in the water column are exposed.

Short-term variability in the amount of suspended chl a may be due to advection of patchily distributed populations, resuspension of benthic assemblages and/or changes in the balance between growth and grazing. Changes due to advection are largely driven by tides (Cloern et al. 1989, Powell et al. 1989, Litaker et al. 1993) but discrete patches of phytoplankton may coalesce or disperse when wind speeds vary (Levasseur et al. 1983) or when frontal zones in salinity interact with flooding and ebbing tides (Dustan \& Pinckney 1989). Advection is responsible for the variability in suspended chl a concentrations observed in comparatively deep ( $>5 \mathrm{~m}$ deep) estuaries, such as the St. Lawrence (Canada) (Sinclair et al. 1980) and South San Francisco Bay (California, USA) (Cloern et al. 1989, Powell et al. 1989). Resuspension of benthic microalgae has been inferred to cause much of the variability in chl a concentration in shallow estuaries (Baillie \& Welsh 1980, Walker 1981, Demers et al. 1987 , Shaffer \& Sullivan 1988, Sullivan \& Moncrieff 1988 , Cloern et al. 1989, de Jonge \& van Beusekom 1992, but see Litaker et al. 1993). Productivity in the water column of turbid estuaries may even be dominated by resuspended benthic algae (Shaffer \& Sullivan 1988, de Jonge \& van Beusekom 1992). Further variability in suspended chl a on diel time-scales may be due to a change in the balance between grazing and the growth of suspended microalgae (Litaker et al. 1988, 1993). The dominant frequencies of change in chl a concentration are therefore the same as those of changes in the clarity of the water column. Both vary on shorter time-scales than the diel variability associated with the day/night cycle.

The effect of this short-term variability on productivity depends on the covariance of changes in turbidity and microalgal biomass and on any changes in the photosynthetic responses of the microalgae. Resuspension of sediment alone would cause a drop in systemlevel productivity because of the decrease in light availability. This depression can be offset where photosynthetically-competent benthic algae are resuspended in association with the sediment because an increase in algal biomass compensates for the decrease in light availability. Covariance between shortterm (hours) changes in chl a and turbidity has been shown in several studies (Demers et al. 1987, Cloern et al. 1989, Powell et al. 1989, Litaker et al. 1993). There may also be secondary effects on productivity due to changes in the photosynthetic responses of the entrained microalgae. Where benthic algae differ in photosynthetic responses from the suspended population (MacIntyre \& Cullen 1995), their resuspension will cause a change in the bulk responses of the resultant suspended population. Further variability in the photosynthetic responses of the phytoplankton during the day may be due to endogenous diel rhythms (Harding et al. 1982) or photoinhibition (Vincent et al. 1984 , Elser \& Kimmel 1985, Neale \& Richerson 1987).

The effect of the short-term variability in chl $a$, turbidity and photosynthesis-irradiance response on productivity depends on the degree to which changes occur in concert. Changes in one parameter may compensate for changes in another (e.g. the increase in chl $a$ and turbidity due to resuspension or a reduction in the rate of photosynthesis with decreased turbidity due to photoinhibition) and the variability may have little effect on productivity. Where the parameters vary independently, though, the effects of changes may be cumulative and may exert a profound effect on productivity. We describe here temporal scales of variability in San Antonio Bay, a shallow and turbid estuary on the coast of Texas, USA. Our objectives were, first, to assess the magnitude and time-scales of variation in those parameters that determine the rate of productivity (light availability and algal biomass and photosynthetic response), second, to determine the extent of coupling between the suspended and benthic populations of microalgae, and third, to assess the effects of these interactions on system-level productivity.

\section{METHODS}

San Antonio Bay is a medium-sized bay (ca $15 x$ $30 \mathrm{~km}$ ) with a freshwater inflow from the Guadalupe River in the north and some tidal exchange with the Gulf of Mexico, from which it is separated by a barrier island, via Espiritu Santo Bay and Cavallo Pass (Fig. 1). The water depth in the bay varies between about $1 \mathrm{~m}$ in the northern part, adjacent to the inlet 


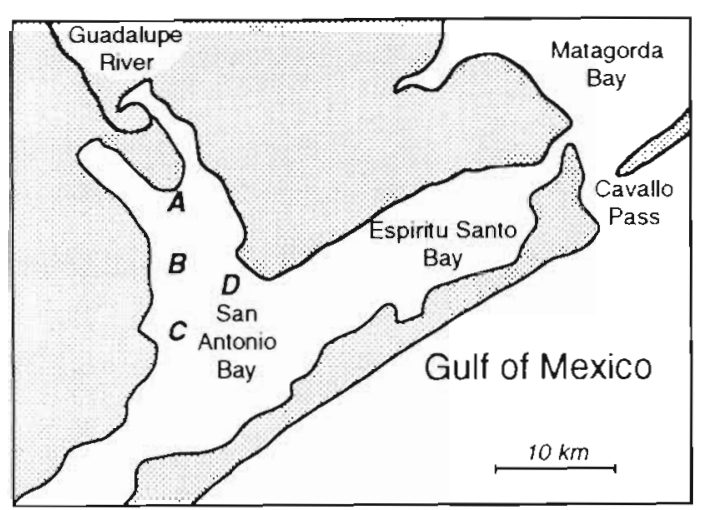

Fig 1 San Antomo Bay, Texas, and the 4 sites (A-D) from which samples were taken

from the Guadalupe, to $2.5 \mathrm{~m}$ in the south. The bay was sampled between November 1986 and July 1987 as part of a program designed to characterize the shallow, lagoonal bays on the southern coast of Texas

Data from the bay are compared with data collected from cultures of the diatom Thalassiosira pseudonana (Clone 3H, obtanned from the Center for the Culture of Marme Phytoplankton, Bigelow Laboratory, Boothbay Harbor, ME, USA). Cultures were grown in 21 polycarbonate bottles in autoclaved filtered sea water (30 PSU) enriched to $f / 2$ nutrient concentrations with. $100 \mu \mathrm{M}$ sllicate (Guillard 1975) and $10 \mathrm{nM}$ selenium (Keller et al. 1987). Cells were maintained at $20^{\circ} \mathrm{C}$ under nutrient-replete conditions (i.e. in log-phase growth, as determined daly from cell counts, chl a concentration and in vivo fluorescence in the absence and presence of $\mathrm{DCMU}_{\text {; }}$ see below). Cultures were stirred and bubbled with air that was passed through an activated charcoal filter and a $0.2 \mu \mathrm{m}$ pore Acrodisc filter before entenng the culture vessels. Illumination of 10 to $900 \mu \mathrm{mol} \mathrm{m} \mathrm{m}^{2} \mathrm{~s}^{-1}$ was provided on a 12 h light: 12 h dark cycle by cool-white fluorescent lights.

Based on a prelmmnary survey, 4 sampling sites in the bay were chosen as representative of the salinity gradient down the bay (Sites $A, B$ and $C$ ) and the tidally-dominated influx from Espiritu Santo Bay (Site D) Sites $A$ and $C$ were occupied for a full day each in November. January. April and July. Site C was also occupied over a $24 \mathrm{~h}$ period, beginning at midday, in March and June. Al] 4 sites were sampled at least once, close to midday, on each sampling trip. Sampling consisted of a vertical profile of physical parameters and discrete water samples taken from the top and bottom of the water column. The discrete samples were analyzed for turbidity (to estimate light attenuation), chlorophyll a (chl a) concentration and in vivo fluores- cence. Photosynthesis-irradiance $(P-I)$ curves were measured in surface and bottom waters for all midday samples and for samples taken at daybreak and dusk at Sites $\mathrm{A}$ and $\mathrm{C}$. The benthos was sampled for all midday samples for vertical profiles of chl a concentration and light attenuation. P-I curves for benthic microalgae were determined for the 0 to 1 and 2 to $3 \mathrm{~mm}$ strata in parallel to samples for the water column (i.e. for all midday samples and at dawn and dusk at Sites $A$ and $\mathrm{C}$ ).

Vertical profiles of temperature, salinity (as conductivity), $\mathrm{pH}$ and dissolved oxygen were obtained with a submersible Hydrolab sonde (Austin, TX). A vertical profile of photosynthetically available quantum scalar irradiance through the water column was measured using a submersible Biospherical Instruments, (San Diego, CA, USA) QSP-170 $4 \pi$ detector with a QSR-240 $4 \pi$ reference sensor. The output from the reference was integrated by a QSR-250 integrator to provide a record of daily incident radiation.

Discrete samples were taken from the surface and bottom of the water column with a 21 LaMotte water sampler (LaMotte Chemical, Chestertown, MA). The bottom sample was taken $20 \mathrm{~cm}$ above the bottom and great care was taken to avoid disturbing the benthos while sampling. Suspended chl a was measured fluorometrically using a Turner Designs (Sunnyvale, CA) 10-005R fluorometer, calibrated against chl a, after correction for degradation products by acidification (Holm-Hansen 1978). Samples were collected by filtration through a Whatman GF/F filter and extracted in pre-chilled $90 \%$ acetone for 24 to $48 \mathrm{~h}$ at $-4{ }^{\circ} \mathrm{C}$ in the dark. Fluorescence in vivo was measured in the presence and absence of DCMU (3-[3,4-dichlorophenyl]1,1-dimethylurea), added as a $3 \mathrm{mM}$ solution in ethanol to a final concentration of $30 \mu \mathrm{M}$ (Vincent et al. 1984) after the sample was dark-adapted for 20 to $30 \mathrm{~min}$. Data are presented as $F_{v} C_{h l^{-1}}$. Variable fluorescence, $F_{\mathrm{v}}$ is equivalent to $F_{\mathrm{m}}-F_{0}$, where $F_{0}$ is fluorescence in the absence of and $F_{\mathrm{m}}$ is fluorescence in the presence of DCMU, and is an index of the number of functional photosystem II (PS II) reaction centers (Vincent et al. 1984). The dimensionless parameter $F_{v} \mathrm{Chl}^{-1}$ is the ratio of $F_{\mathrm{v}}$ to the fluorescence of the equivalent chl a concentration in vitro when the cells are extracted in acetone (Kiefer 1973) and is a crude estimate of the proportion of functional PS II reaction centers.

Turbidity in the samples was measured as side-scatter, using a Hach (Loveland, CO, USA) 2100 Turbidimeter calibrated against a 10 Jackson Turbidity Unit (JTU) latex standard supplied by the manufacturer. Samples with turbidity higher than $10 \mathrm{JTU}$ were diluted with Milli-Q water before measurement. Measurements of turbidity were converted to a diffuse attenuation coefficient, $k\left(\mathrm{~m}^{-1}\right)$, using a regression of 
the attenuation coefficient, obtained with the Biospherical Instruments light meters $\left(0.7\right.$ to $\left.15.3 \mathrm{~m}^{-1}\right)$, versus turbidity (JTU) in the surface samples. The regression is based on data collected at all sites during all sample periods except March.

$$
k=0.14 \cdot \text { Turbidity }+0.71\left(R^{2}=0.94, n=89\right)
$$

Symbols and abbreviations used in this paper are summarized in Table 1. Application of Eq. (1) requires the assumption of a constant relationship between absorption and scattering in the suspended material (Kirk 1985). The variable contribution to absorption of the phytoplankton, which ranged between 4 and

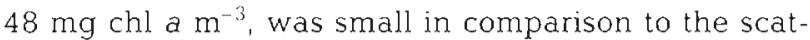
tering by inorganic particulates, and the relationship in Eq. (1) agrees well with that published by Walmsley et al. (1980). Conversion of turbidity to an attenuation coefficient allowed estimation of the light attenuation through the water column where it was not well-mixed and for samples taken in March, when the light meter was unavailable. For consistency, all values of $k$ used to determine productivity are those calculated from Eq. (1).
Mean irradiance in the water column, $I_{\mathrm{d} w}$, was calculated according to Neale et al. (1991):

$$
I_{\mathrm{dr}}=\left(\frac{I_{0}}{k \cdot z_{\mathrm{m}}}\right) \cdot\left[1-\exp \left(-k \cdot z_{\mathrm{m}}\right)\right]
$$

where $I_{0}$ is incident irradiance and $z_{\mathrm{m}}$ is the depth of the water column.

A scuba diver sampled the benthos in a $0.5 \times 0.5 \mathrm{~m}$ grid, using acrylic cores $(25 \mathrm{~mm}$ inner diameter) Twelve cores were taken for each midday sample: 4 for determination of pigment profiles, 4 for determination of light attenuation in the sediment, and 4 for measurement of $P-I$ curves. The sediment was extruded from the core using a micromanipulator (Joint et al. 1982) and sectioned in $1 \mathrm{~mm}$ slices. Chl a concentration was determined as for the suspended samples, except that the sediment was added directly to $90 \%$ acetone (cf. Phinney \& Yentsch 1985) and the samples were centrifuged for $5 \mathrm{~min}$ at $4000 \times g$ and diluted before reading in the fluorometer. The attenuation coefficient in the sediment was estimated by measuring the transmission of spectral irradiance through the upper millimeter of sediment suspended and resettled over the

\begin{tabular}{|c|c|c|}
\hline Symbol & Definition & Units \\
\hline$\alpha^{\text {thl }}$ & Initial slope of the $P$-I curve & $\mathrm{gC}(\mathrm{gchl} a)^{-1}(\mu \mathrm{mol} \text { photons })^{-1} \mathrm{~m}^{2}$ \\
\hline$B Z I$ & Composite parameter estimating $\prod_{\mathrm{dhy}}=\mathrm{Chl} \times z_{\mathrm{PU}} \times I_{I m}$ & $\mathrm{~g} C \mathrm{~m}^{-2}$ mol photons $\mathrm{m}^{-2} \mathrm{~d}^{-1}$ \\
\hline$\beta^{\text {chl }}$ & Photoinhibition parameter of the $P$-I curve & $g C(\mathrm{~g} \mathrm{chl} a)^{-1}$ ( $\mu \mathrm{mol}$ photons $)^{-1} \mathrm{~m}^{2}$ \\
\hline Chl & Chlorophyll a concentration & $\mathrm{mg} \mathrm{m}^{-3}$ \\
\hline$D$ & Length of the photoperiod & h \\
\hline$F_{0}$ & Dark-adapted fluorescence in vivo in the absence of DCMU & Arbitrary units \\
\hline$F_{m}$ & Dark-adapted fluorescence in vivo in the presence of DCMU & Arbitrary units \\
\hline$F_{\mathrm{v}}$ & Variable fluorescence $_{1}=F-F_{0}$ & Dimensionless \\
\hline$F_{\mathrm{v}} C h l^{-1}$ & Ratio of $F$, to fluorescence of equivalent chl a concentration in vitro & Dimensionless \\
\hline$I_{a v}$ & Mean irradiance in the water column & $\mu \mathrm{mol} \mathrm{m} \mathrm{m}^{-2} \mathrm{~s}^{-1}$ \\
\hline$I_{\mathrm{d}}$ & Mean incident irradiance over the course of a day & $\mu \mathrm{mol} \mathrm{m} \mathrm{s}^{-1}$ \\
\hline$I_{\mathrm{int}}$ & Total incident irradiance over the course of a day & $\mathrm{mol} \mathrm{m} \mathrm{m}^{-2} \mathrm{~d}^{-1}$ \\
\hline$I_{k}$ & Saturation parameter of the $P$-I curve, $=P_{\mathrm{m}}^{\mathrm{chl}} / \alpha^{\mathrm{chl}}$ & umol m-2 $\mathrm{s}^{-1}$ \\
\hline$I_{n}$ & Incident irradiance at noon & $\mu \mathrm{mol} \mathrm{m} \mathrm{m}^{-2} \mathrm{~s}^{-1}$ \\
\hline$I_{0}$ & Incident irradiance & umol m-2 $\mathrm{s}^{-1}$ \\
\hline 1, & Irradiance at depth $z$ & $\mu \mathrm{mol} \mathrm{m} \mathrm{m}^{-2} \mathrm{~s}^{-1}$ \\
\hline k & Diffuse altenuation cnefficient & $\mathrm{m}^{-1}$ or $\mathrm{mm}^{-1}$ \\
\hline$M$ & Composite parameter in Eq. $9_{4}=P_{\mathrm{m}}^{\mathrm{chl}} \times \mathrm{Chl/K}$ & $\mathrm{gC} \mathrm{m}^{-2} \mathrm{~h}^{-1}$ \\
\hline P-I & Photosynthesis versus irradiance & \\
\hline$P_{\mathrm{m}}^{\mathrm{chl}}$ & Light-saturated rate of chlorophyll-specific photosynthesis & $\mathrm{gC}(\mathrm{gchl} a)^{-1} \mathrm{~h}^{-1}$ \\
\hline$\Pi(t)$ & Areal productivity at time $t$ & $\operatorname{mgC~m} \mathrm{Cm}^{-2}$ \\
\hline$\prod_{t(t)}$ & Areal productivity at irradiance $I_{0}$ and time $t$ & $\mathrm{mgC} \mathrm{m} \mathrm{m}^{-2} \mathrm{~h}^{-1}$ \\
\hline$\prod_{\text {day }}$ & Daily areal productivity calculated by interpolation of $\prod_{11 !}$ & $g C \mathrm{~m}^{-2} \mathrm{~d}^{-1}$ \\
\hline$\prod_{\text {noon }}$ & Areal productivity at noon & $\mathrm{mgC} \mathrm{m} \mathrm{m}^{-1}$ \\
\hline$\prod_{\text {day }}$ & Daily areal productuvity calculated by extrapolation of $\Pi_{\text {noun }}$ & $\mathrm{gCm} \mathrm{m}^{-2} \mathrm{~d}^{-1}$ \\
\hline$C V_{\mathrm{exp}}$ & Expected within-day coefficient of variation in $M$ & Dimensionless \\
\hline$C V_{o b s}$ & Observed within-day coefficient of variation in $M$ & Dimensionless \\
\hline$z_{\mathrm{ke}}$ & Depth of the euphotic zone, $=4 \cdot 6 /-k$ & $\mathrm{~m}$ \\
\hline$z_{\mathrm{m}}$ & Depth of the water column & $\mathrm{m}$ \\
\hline$z_{m u}: z_{m}$ & Ratio of $z_{\mathrm{eU}}$ to $z_{\mathrm{m}}$ & Dimensionless \\
\hline
\end{tabular}

Table 1 . Symbols, terms and abbreviations used in the text 
sensor of an ISCO Model SR spectroradiometer (MacIntyre \& Cullen 1995). Measurements were taken at $50 \mathrm{~nm}$ intervals between 400 and $750 \mathrm{~nm}$ and averaged to give a mean coefficient.

$P$-I curves for both the water column and benthos were determined from ${ }^{14} \mathrm{C}$-bicarbonate uptake in a 'photosynthetron' (Lewis \& Smith 1983), as described by MacIntyre \& Cullen (1995). Benthic samples were resuspended in GF/F-filtered water from the sample site. Light in the incubator was provided by 4 General Electric ENH projection lamps and filtered through successive $2.5 \mathrm{~cm}$ filters of water and $10 \mathrm{mg} \mathrm{l}^{-1}$ copper sulfate solution. Irradiances were measured with the QSP-170 $4 \pi$ sensor. The $P$-I curve was constructed by fitting the data to the equation of Platt et al. (1980):

$$
P^{\mathrm{chl}}=P_{\mathrm{s}}^{\mathrm{chl}} \cdot\left[1-\exp \left(\frac{-\alpha^{\mathrm{chl}} \cdot I}{P_{\mathrm{s}}^{\mathrm{chl}}}\right)\right] \cdot \exp \left(\frac{-\beta^{\mathrm{chl}} \cdot I}{P_{\mathrm{s}}^{\mathrm{chl}}}\right)+P_{0}^{\mathrm{chl}}
$$

where $P^{\text {chl }}$ is the rate of photosynthesis, normalized to chl a $\left[\mathrm{g} \mathrm{C}(\mathrm{g} \mathrm{chl} a)^{-1} \mathrm{~h}^{-1}\right]$ at irradiance $I$ ( $\mathrm{mmol}$ photons $\left.\mathrm{m}^{-2} \mathrm{~s}^{-1}\right) ; P_{\mathrm{s}}^{\mathrm{chl}}\left[\mathrm{g} \mathrm{C}(\mathrm{g} \mathrm{chl} a)^{-1} \mathrm{~h}^{-1}\right]$ is the maximum rate of photosynthesis in the absence of photoinhibition; $\left.\alpha^{\mathrm{chl}}\left[\mathrm{gC}(\mathrm{g} \mathrm{chl} a)^{-1} \text { ( } \mathrm{mmol} \text { photons }\right)^{-1} \mathrm{~m}^{2}\right]$ is the initial slope of the P-I curve, and $\beta^{\text {chl }}$ Ig C $(g \mathrm{chl} a)^{-1}$ ( $\mu \mathrm{mol}$ photons $)^{-1} \mathrm{~m}^{2}$ ] is a parameter describing the reduction in photosynthesis at high irradiance. $P_{0}^{\text {chl }}\left[\mathrm{g} \mathrm{C}(\mathrm{g} \mathrm{chl} \mathrm{a})^{-1}\right.$ $\left.\mathrm{h}^{-1}\right\}$ is an intercept term, subtracted from $P^{\text {chl }}$ so that modeled photosynthesis in the dark is always zero. Parameters were fit simultaneously using the multjvariate secant method (Ralston \& Jennrich 1978) of the NLIN procedure of SAS (SAS Institute Inc., Cary, NC). The light-saturated rate of photosynthesis, $P_{\mathrm{m}}^{\mathrm{chl}} \mathrm{Ig} C(\mathrm{~g}$ chl a) ${ }^{-1} h^{-1}$, was calculated as

$$
P_{m}^{c h l}=P_{s}^{c h l}\left(\frac{\alpha^{c h l}}{\alpha^{c h l}+\beta^{c h l}}\right) \cdot\left(\frac{\beta^{c h l}}{\alpha^{c h l}+\beta^{c h l}}\right)^{\frac{\beta^{c h l}}{\alpha^{c h l}}}
$$

The error of $P_{\mathrm{m}}^{\mathrm{chl}}$ was calculated as described by Davis (1986), according to principles described by Zimmerman et al. (1987). The degree to which photosynthesis declines at high irradiance was described by the index $P_{\mathrm{m}}^{\mathrm{chl} /} / P_{\mathrm{s}}^{\mathrm{chl}}$, the ratio of the realized light-saturated rate of photosynthesis to the maximum rate that would be obtained in the absence of photoinhibition. The fall-off in photosynthesis becomes less pronounced, and the $P$ - $I$ curve flatter, as the ratio tends to unity.

Productivity in the water column was calculated by integrating photosynthetic rates over depth and time. Photosynthesis at depth $z, P(z)\left(\mathrm{mg} \mathrm{C} \mathrm{m}^{-3} \mathrm{~h}^{-1}\right)$, was calculated from the vertical profile of light intensity, the chl a concentration $(C h l)$ and the $P$-I curve:

$$
P(z)=C h l \cdot P_{s}^{c h l}\left[1-\exp \left(\frac{-\alpha^{\mathrm{chl}} \cdot I(z)}{P_{\mathrm{s}}^{\mathrm{chl}}}\right)\right] \cdot \exp \left(\frac{-\beta^{\mathrm{chl}} \cdot I(z)}{P_{\mathrm{s}}^{\mathrm{chl}}}\right)
$$

where irradiance at depth $z$ is

$$
I(z)=I_{0} \cdot \exp (-k \cdot z)
$$

Two profiles of $P(z)$ were constructed for each set of samples, one using the parameter values (i.e. $k, C h l$ and $P-I$ parameters) determined on the surface sample and the second using the parameters from the bottom sample. To account for the vertical variation in $k, C h l$ and $P$-I parameters, a third profile was constructed from the depth-weighted averages of these 2 estimates of photosynthesis (cf Cullen et al. 1992). The resultant profile was integrated over depth to give areal productivity, $\prod(t)\left(\mathrm{mg} \mathrm{C} \mathrm{m}^{-2} \mathrm{~h}^{-1}\right)$ :

$$
\Pi(t)=\sum_{z=0}^{z=z_{m}} P(z) \cdot \Delta z
$$

where $\Delta z$ is $0.01 \mathrm{~m}$. The limit with respect to depth $(z=$ $Z_{\mathrm{m}}$ ) was the depth of the water column.

Where a site was occupied for a day, a vertical profile of productivity was determined for each pair of samples (surface and bottom) taken from the water column. Paired samples were taken every 1 to $2 \mathrm{~h}$ for chl a concentrations and light attenuation coefficients, but $P$-I curves were measured only at dawn, midday and dusk. The photosynthetic parameters were interpolated linearly between daybreak and midday or midday and dusk values for the remaining samples. Daily productivity, $\prod_{\text {day }}\left(\mathrm{g} C \mathrm{~m}^{-2} \mathrm{~d}^{-1}\right.$ ), was calculated by integration of successive values of $\Pi(t)$ from sunrise $(t=0)$ to sunset $(t=$ day length, $D)$ :

$$
\Pi_{\mathrm{day}}=\sum_{i=0}^{t=D} \Pi(t) \cdot \Delta t
$$

where $\Delta t$ is 1 to $2 \mathrm{~h}$, the interval between successive samples.

Productivity in the benthos was calculated from the light intensity incident on the sediment and the attenuation coefficient, chl a concentration and $P-I$ parameters measured in the upper millimeter of benthos using Eqs. (5) to (8). (Only 0.01 to $0.1 \%$ of light incident on the sediment was transmitted through the surficial millimeter.) Daily productivity was calculated by integrating these vertical profiles with respect to depth and time, as for the water column, except that $\Delta z$ (Eq. 6) was $0.05 \mathrm{~mm}$. The technique used to measure light attenuation through the sediment is insensitive to backscatter, which can increase light intensities in sandy sediment by $100 \%$ (Kühl \& Jørgensen 1994). However, the sediment at the 4 sites studied was fine, reducing the magnitude of the error due to backscatter, and rates of production in the benthos were very low in comparison to those in the water column (see 'Results'). The error in estimating overall productivity at each site should be small. 

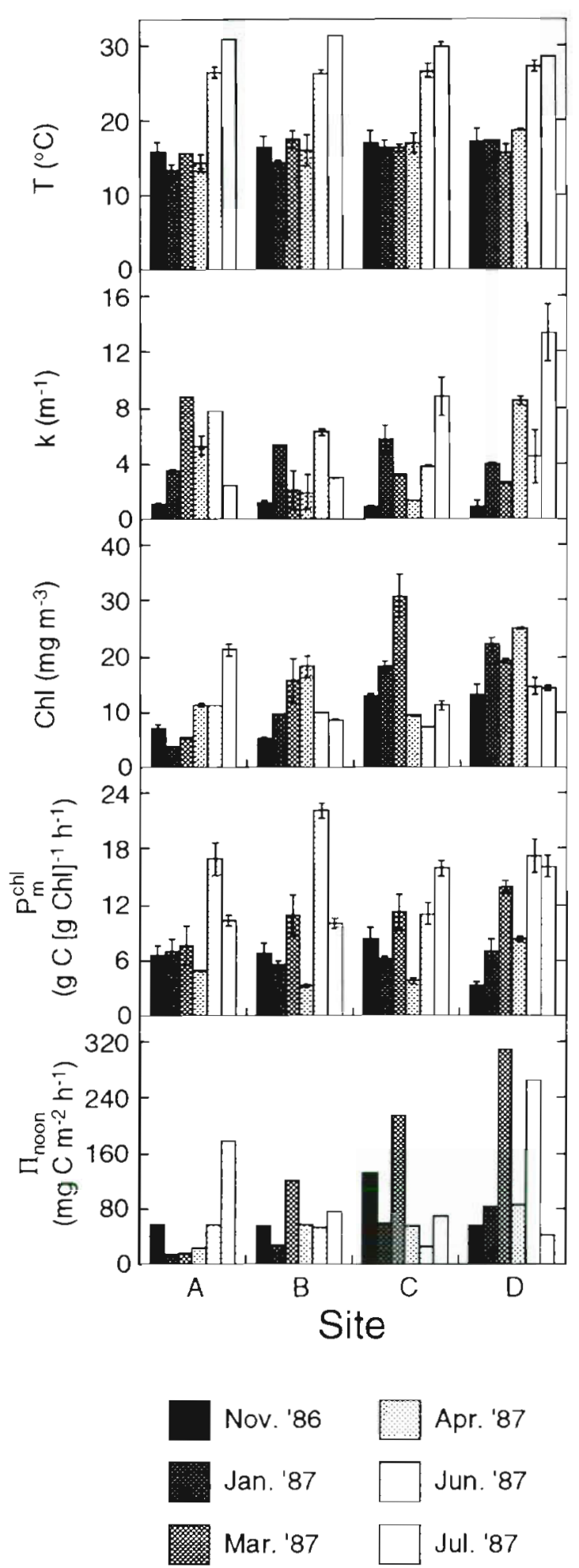

Fig. 2. Variation in the midday values of water temperature $(T)$, the attenuation coefficient $(k), \mathrm{chl}$ a concentration $(C h I)$, photosynthetic capacity $\left(P_{\mathrm{m}}^{\mathrm{chl}}\right)$ and areal productivity $\left(\prod_{\text {noon }}\right)$ in the water column by site and by month. Data are the mean of surface and bottom samples: error bars are the range of values

\section{RESULTS}

\section{Month-to-month variability in the water column}

Freshwater inflow into San Antonio Bay from the Guadalupe River was 0.6 to $2.3 \times 10^{6} \mathrm{~m}^{3} \mathrm{~d}^{-1}$ during most of the study, but rose during June and July to a peak of $7.6 \times 10^{6} \mathrm{~m}^{3} \mathrm{~d}^{-1}$ (Whitledge 1989), resulting in a drop in salinity throughout the bay in June and July. There was concomitant warming, with water temperatures of 26 to $33^{\circ} \mathrm{C}$ in June and July, as compared to 12 to $19^{\circ} \mathrm{C}$ in the previous months (Fig 2). Inorganic nutrient concentrations in the water column were high throughout the sampling period, ranging between 10 and $80 \mu \mathrm{M}$ nitrate, 0.2 and $40 \mu \mathrm{M}$ ammonium, 0.5 and $16 \mathrm{mM}$ phosphate and 80 and $210 \mu \mathrm{M}$ silicate (Whitledge 1989). There was a gradient of increasing salinity from north to south and from west to east during the 6 sample periods, suggesting that circulation in the bay was counterclockwise.

The parameters that determine primary productivity, the transparency of the water column and the abundance and photosynthetic response of the suspended microalgae, showed the high variability characteristic of estuarine waters (Fig. 2). Attenuation coefficients, $k$, were high $\left(0.7\right.$ to $15.3 \mathrm{~m}^{-1}$, see 'Discussion' for a comparison with other studies). The highest value corresponds to a $1 \%$ light level at $0.3 \mathrm{~m}$. The overall mean. measured at all sites during all sampling periods, was $4.2 \mathrm{~m}^{-1}$ (SD $\left.=2.7 \mathrm{~m}^{-1}, \mathrm{n}=213\right)$. Chl a concentrations varied by an order of magnitude ( 4 to $48 \mathrm{mg} \mathrm{m}^{-3}$ ) over the sampling period and were comparable with other studies (see 'Discussion'). Light-saturated rates of photosynthesis, $P_{m}^{\mathrm{chl}}$, were 3.0 to $22.9 \mathrm{~g} \mathrm{C}\left(\mathrm{g} \mathrm{chl} \mathrm{a}^{-1} \mathrm{~h}^{-1}\right.$ and midday areal productivity, $\prod_{\text {noon }}$ ranged from 14 to $309 \mathrm{mg} \mathrm{C} \mathrm{m}^{-2} \mathrm{~h}^{-1}$

The attenuation coefficients were lowest in November $\left(0.7\right.$ to $\left.1.6 \mathrm{~m}^{-1}\right)$, when the water column was stratified. Otherwise, there was no clear temporal or spatial pattern in the midday measurements of attenuation at the 4 sites (Fig. 2). Chl a concentrations were highest in March at Site C, in April at Sites B and D, and in July at Site $A$. They were generally higher at Sites $C$ and $D$ than at $A$, with intermediate concentrations at Site B. There was no consistent difference in $P_{\mathrm{m}}^{\mathrm{chl}}$ between the sites. The highest rates were measured in June and July, although rates were also high at Sites B, C and D in March. There were no consistent temporal trends in $\Pi_{\text {noon, }}$ but productivity was generally higher at Sites $C$ and $D$ than at Site $A$, with Site $B$ being intermediate between them.

Correlation analysis of the physical and biological parameters measured in the water column show that variation in any one factor could explain no more than $49 \%$ of the variability in another, when measured on 
Table 2. Pearson correlation coefficients for multiple correlations of midday incident irradiance $\left(I_{0}\right)$, mean irradiance in the water column $\left(I_{\mathrm{a} v}\right)$, water temperature $(T)$ and salinity $(S)$, chl a concentration $(C h l)$, diffuse attenuation coefficient $(k)$, light-saturated and light-limited rates of photosynthesis $\left(P_{\mathrm{m}}^{\mathrm{chl}}\right.$ and $\left.\alpha^{\mathrm{chl}}\right)$ and areal productivity $\left(\Pi_{\text {noon }}\right)$ in the water column. Surface and bottom measurements were averaged in correlations with $\prod_{\text {roon, }}$ otherwise they are treated independently $(n=24$ or 48$)$. $p<0.05$. $\cdots p<0.01, \cdots p<0.001$

\begin{tabular}{|c|c|c|c|c|c|c|c|c|}
\hline & $l_{\mathrm{dv}}$ & $T$ & $S$ & Chl & k & $p_{\mathrm{m}}^{\mathrm{chl}}$ & $\alpha^{c h l}$ & $\prod_{\text {nown }}$ \\
\hline$I_{0}$ & 0.346 & 0.224 & 0.114 & 0.088 & 0.107 & $0.236^{\circ}$ & 0.188 & $0.439 \cdots$ \\
\hline$I_{\mathrm{dv}}$ & & 0.031 & 0.289 & 0.198 & $-0.700 \cdots$ & $-0.424^{\circ}$ & $-0.416^{\circ}$ & 0.120 \\
\hline$T$ & & & $0.258^{\circ}$ & 0.069 & $0.234^{\circ}$ & $0.561 \cdots$ & 0.067 & 0.094 \\
\hline$S$ & & & & 0.145 & $0.485 \cdots$ & $0.232^{\bullet}$ & 0.033 & $0.205^{\circ}$ \\
\hline Chl & & & & & 0.119 & 0.109 & 0.023 & $0.455^{\cdots}$ \\
\hline$k$ & & & & & & $0.484 \cdots$ & 0.139 & $-0.239^{\bullet}$ \\
\hline$p_{\mathrm{m}}^{\mathrm{chl}}$ & & & & & & & $0.449^{\cdots}$ & $0.265^{*}$ \\
\hline$\alpha^{\text {cht }}$ & & & & & & & & 0.183 \\
\hline
\end{tabular}

these temporal and spatial scales (Table 2). The diffuse attenuation coefficient, $k$, was significantly correlated $(p<0.05)$ with both temperature and salinity, Microalgal abundance, measured as chl a concentration, was not significantly correlated with any of the physical parameters, including nutrient concentrations (data not shown). Light-limited photosynthetic rates, $\alpha^{\mathrm{chl}}$, were correlated with light-saturated rates, $P_{\mathrm{m}}^{\mathrm{ch}}$, and inversely correlated with the mean irradiance in the water column. In contrast, $P_{\mathrm{m}}^{\mathrm{chl}}$ was correlated with temperature, salinity, incident irradiance and the attenuation coefficient and negatively correlated with the mean irradiance in the water column. Areal productivity was correlated both with the parameters that determine the light environment (incident irradiance and attenuation in the water column) and with the abundance and photosynthetic response of the microalgae.

\section{Within-day variability in the water column}

The within-day variation of surface and bottom chl a concentrations, attenuation coefficients, in vivo fluorescence and photosynthetic parameters at Sites $A$ and $C$ is shown in Figs. $3 \& 4$. The water column at both sites was strongly stratified in November and showed tidally-driven vertical gradients in salinity at Site $\mathrm{C}$ in the remaining months. Neither vertical gradients nor temporal patterns were detectable in profiles of salinity at Site A in January, April and July. Salinities were lower at Site A than at Site C, consistent with Site A's proximity to the Guadalupe River (Fig 1).

Both chl $a$ and the attenuation coefficient showed marked variations over the course of a day: coefficients of variation (standard deviation/mean, expressed as a percentage) were 16 to $52 \%$ for chl $a$ and 14 to $75 \%$ for the attenuation coefficient. In 5 cases (at Site $A$ in April and Site C in January, April, June and July), fluctuations in attenuation over the course of a single day were almost as great as the range of the entire dataset. There was no consistent pattern of diel variation in the light-limited and light-saturated rates of photosynthesis, $\alpha^{\text {chl }}$ and $P_{\mathrm{m}}^{\mathrm{chl}}$. There was a progressive decline in $P_{\mathrm{m}}^{\mathrm{chl}}$ during the day as often as there was a midday peak. The index of functional PS II reaction centers, $F_{v}{C C h l^{-1}}$, showed either a minimum at midday or a progressive decline through the day at all sites, except at Site $C$ in June and July. Production was restricted to the upper water column by high turbidity at Site $A$ in January and April and at Site C in January, June and July. There were subsurface maxima in modeled productivity for part of the day at Site $A$ in November, January and April and at Site $C$ in November, March and April

\section{Between-day variability in the water column}

Midday samples were taken at Site $C$ on 2 or 3 successive days in March, June and July to examine between-day variability (Fig 5). In the first of the 3 cases shown (March 4 and 5), there was very little change in chl a concentration or attenuation and a $25 \%$ decrease in both $P_{\mathrm{rl}}^{\mathrm{chl}}$ and $\alpha^{\mathrm{chl}}$. This yields a difference in maximal areal productivity (productivity in full sunlight) of about $13 \%$. In the second case (June 3 and 4), a $27 \%$ drop in $P_{\mathrm{m}}^{\mathrm{chl}}$ and $48 \%$ drop in $\alpha^{\mathrm{chl}}$ was more than compensated for by a $55 \%$ increase in light penetration. Maximum areal productivity rate rose by $52 \%$. In the third case (July 15 to 17 ), $P_{\mathrm{m}}^{\mathrm{chl}}$ rose by $57 \%$ and $\alpha^{\text {chl }}$ rose by $64 \%$ in the first $24 \mathrm{~h}$, but attenuation rose by $200 \%$. Maximal areal productivity fell by $44 \%$. During the next $24 \mathrm{~h}, P_{\mathrm{m}}^{\mathrm{chl}}$ rose slightly to $164 \%$ of the initial value while $\alpha^{\text {chl }}$ fell to $67 \%$ of the initial value and attenuation rose by a further $15 \%$. 


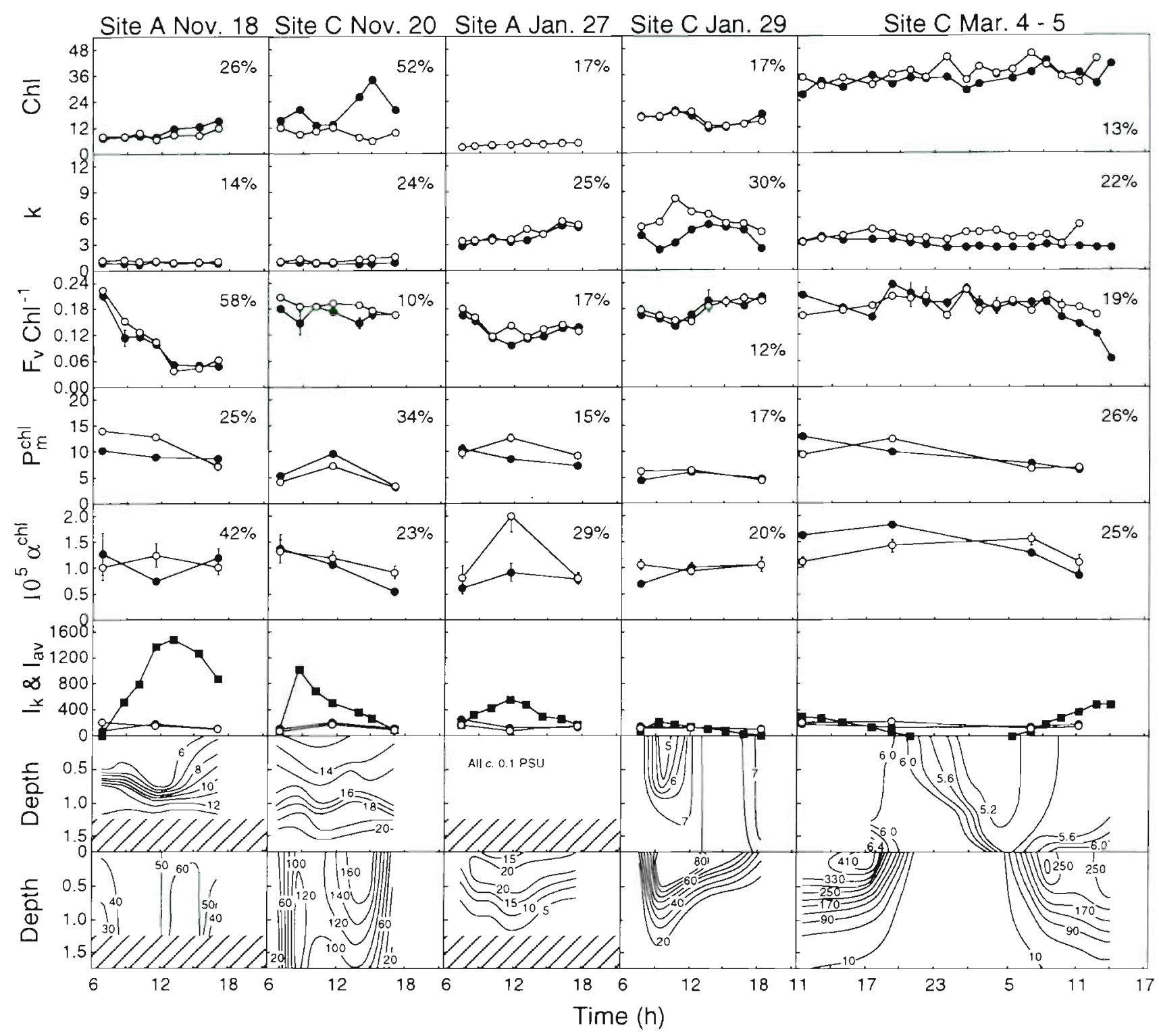

Fig. 3. Varlation in chl a concentration $(C h l)$, the attenuation coefficient $(k)$, chlorophyll-specific variable fluorescence $\left(F_{v} C h l^{-1}\right)$, the light-saturated and light-limited rates of photosynthesis $\left(P_{\mathrm{m}}^{\mathrm{chl}}\right.$ and $\alpha^{\mathrm{chl}}$ ) and the saturation parameter of the $P$ - $I$ response $\left(I_{k}\right)$ at the surface ( ) and bottom (o) of the water column. Samples were taken during $5 \mathrm{~d}$ (November 1986 and January and March $1987)$ at Sites $A$ and $C$ in San Antonio Bay. Mean irradiance in the water column $\left(I_{d w} \mathbf{m}\right)$ is shown with $I_{k}$. See table 1 for units. Coefficients of vanance (\%) for each parameter are given in each panel. For depth, the upper row of contour plots are of salinity (PSU) and the lower row are of productivity, $P(z),\left(\mathrm{mg} \mathrm{C} \mathrm{m}^{-3} \mathrm{~h}^{-1}\right.$ )

Maximal areal productivity fell to $79 \%$ of the value on the previous day and $44 \%$ of the value on the first day. The between-day variations in productivity were almost as large as those observed between sites in a given month or between months at a single site (Fig. 2). Changes in the $P$-I response (i.e. $P_{m}^{\text {chl }}$ and $\alpha^{\text {chil }}$ ) occurred in parallel with changes in the fluorescence parameter $F_{v} C h l^{1}$ and in opposition to changes in the mean irradiance in the water column (Fig. 5).

\section{Photosynthetic responses of the suspended microalgae}

The photosynthetic responses of the suspended microalgae varied with sampling time, irradiance and temperature. Diel variability was examined by comparing data from Sites $A$ and $C$ where $P$-I parameters were measured over the course of a day. Data were standardized to the within-day mean to obviate vari- 


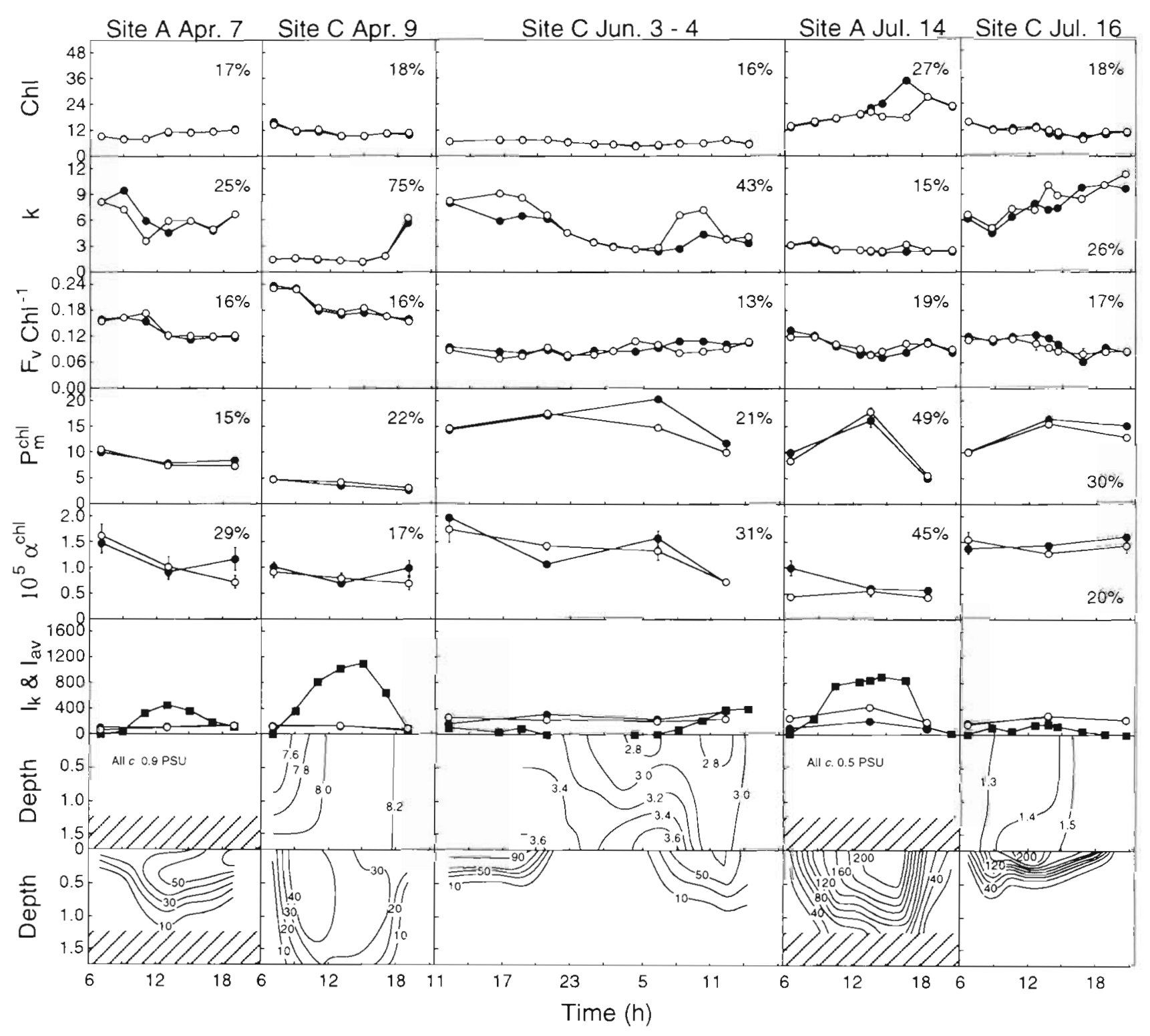

Fig. 4. As for Fig. 3 but for samples taken in April, June and July 1987

ability that occurs on longer time-scales. Standardized values of $P_{\mathrm{m}}^{\mathrm{chl}}$ varied significantly $(\mathrm{p}<0.001$. ANOVA) over a day, when grouped by sample period (Fig. 6A). There was no significant difference between samples taken at dawn and other times. Samples taken at dusk were lower than those taken at midday ( $p<0.05$, Sheffé's a posteriori comparison). Variability was comparable in range but less coherent than that in nutrient-replete cultures of the diatom Thalassiosira pseudonana grown on a $12 \mathrm{~h}$ light: $12 \mathrm{~h}$ dark cycle (Fig. 6C). There was no significant difference between standardized values of $\alpha^{\mathrm{chl}}$ in the natural assemblage. Standardized values of $F_{v} \mathrm{Chl}^{-1}$ varied significantly over the day $(\mathrm{p}<0.001)$ but the pattern differed from that in $P_{\mathrm{m}}^{\mathrm{chl}}$ (Fig. 6B). Standardized values were highest at dawn and lowest at midday. There was some recovery by dusk but dusk values were still lower than those at dawn. In contrast, standardized values of $F_{\mathrm{v}} \mathrm{Chl}^{-1}$ in the cultures of $T$. pseudonana showed a peak in the mid-morning, coincident with the peak in $P_{\mathrm{m}}^{\mathrm{chl}}$ (Fig. 6D), and were lowest at dusk. The $P$-I curves of the natural assemblage were also flatter than those of $T$. pseudonana, showing less of a reduction in photosynthesis at high irradiance, as measured by the index $P_{\mathrm{m}}^{\mathrm{chl}} / P_{\mathrm{s}}^{\mathrm{chl}}(\mathrm{p}<0.01$, Kruskal-Wallace ANOVA). The ratio averaged $0.93(\mathrm{SD}=0.09, \mathrm{n}=96)$ in the natural assemblage, as compared to $0.86(\mathrm{SD}=0.11, \mathrm{n}=75)$ in $T$. pseudonana. 


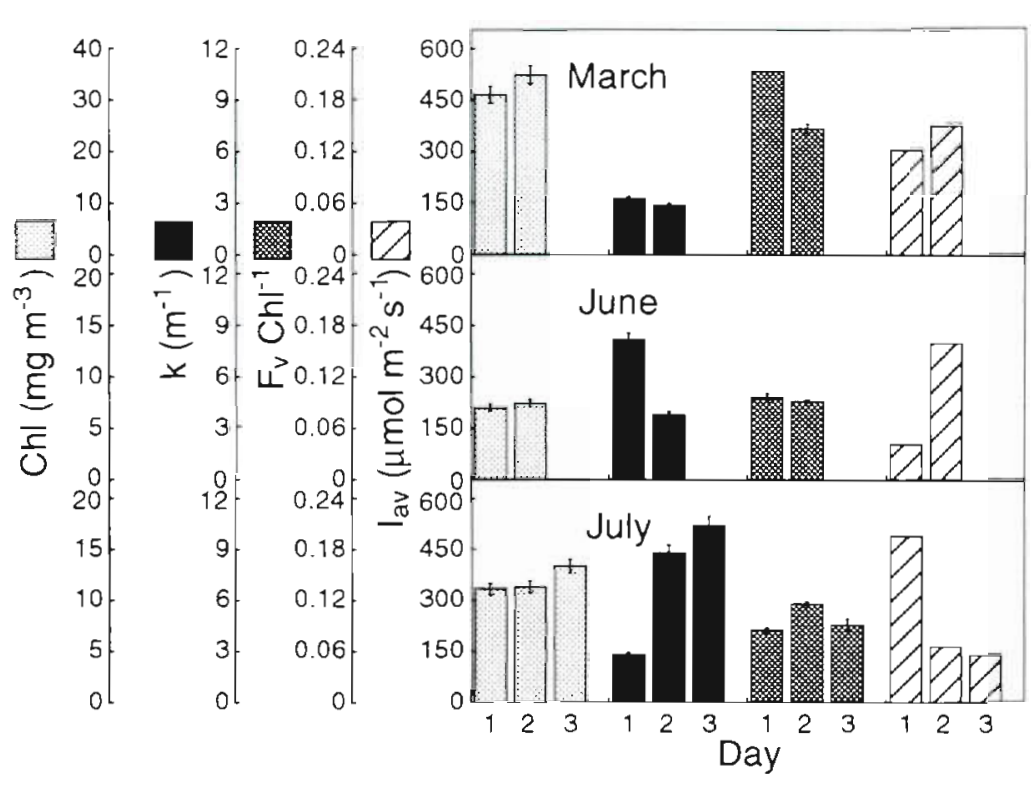

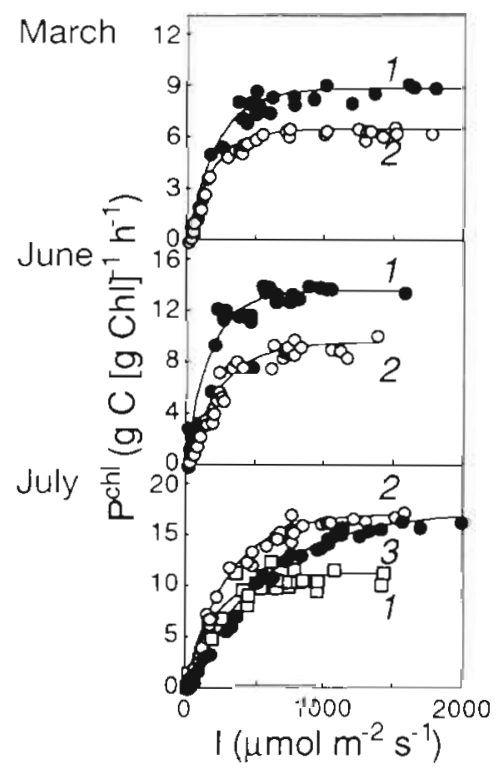

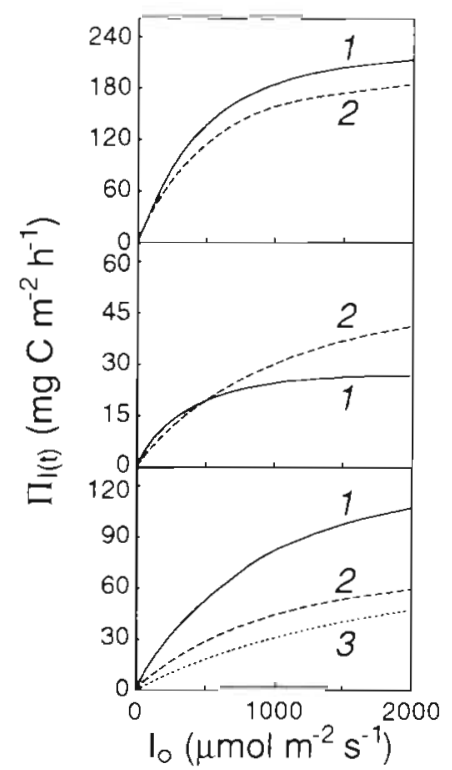

Fig. 5. Variation in midday measurements of chl a concentration (Chl), the attenuation coefficient $(k)$, variable fluorescence $\left(F_{y}\left(C h^{-1}\right)\right.$, the mean irradıance in the water column $\left(I_{\mathrm{d} y}\right)$, the $P$ - $I$ response and potential areal productivity $\left(\Pi_{h, l}\right\}$ in the water column at Site $C$ over 2 or 3 consecutive days. Error bars are the rance of surface and bottom values. Potential areal productivity is shown as a function of incident irradiance to allow companson between days where irradiance differed. Data were collected on March 4 and 5, June 3 and 4 and July 15 to 17,1987 . Italicized numbers on plots of $P$ versus $I$ and $\prod_{t(t)}$ versus $I_{0}$ refer to the day on which data were collected

at Site C) were both occasions on which the mean irradiance in the water column was lower than $I_{k}$, the saturation parameter of the $P$-I curve (Fig. 4), and on which the initial values of $F_{v} \mathrm{Chl}^{-1}$ were low. There was a hysteresis in the trend between morning and afternoon values such that afternoon values of $\mathrm{F}_{\mathrm{v}} \mathrm{Chl}^{-1}$ were lower than the morning values in 5 of the 7 cases where the comparison could be made (Site $A$ in all months and Site $C$ in November, January and April). Because Site $C$ was occupied from noon to noon in March and June, the afternoon values precede the morning values and cannot be used to assess any recovery.

To avoid differences due to diel variability, the effects of irradiance and temperature on $P_{\mathrm{m}}^{\mathrm{chl}}$ were examined on samples taken at midday at all sites. Midday values of $P_{\mathrm{m}}^{\mathrm{chl}}$. which were measured within an hour of local noon, were comparable to or higher than those of Thalassiosira pseudonana grown on the $12 \mathrm{~h}$ light: 12 h dark cycle and sampled 3,6 and $9 \mathrm{~h}$ after the beginning of the light period (Fig. 8A, B). However, while $P_{\mathrm{m}}^{\mathrm{chl}}$ in the culture varied with the $\log$ of irradiance $\left(p<0.001, R^{2}=0.82\right), P_{m}^{\text {chl }}$ in the suspended assemblage varjed inversely with the log of mean irradiance in the water column, $I_{\mathrm{dv}},\left(\mathrm{p}<0.05, \mathrm{R}^{2}=0.18\right)$. The mean irradiance and water temperature were not correlated, but the variation of $P_{\mathrm{m}}^{\mathrm{chl}}$ with mean irradiance was corrected for temperature effects by regressing $\log \left(P_{\mathrm{m}}^{\mathrm{chl}}\right)$ on temperature (Fig. 8C). There was a break in the distribution of data because of a rise in water temperature of $7^{\circ} \mathrm{C}$ between the March and June sampling trips (Fig. 2). The regression was significant $\left(p<0.001, R^{2}=0.46\right)$ and the slope, 0.025 , yielded a $Q_{10}$ value of 1.8 .

The effect of irradiance on $P_{\mathrm{m}}^{\mathrm{chl}}$, independent of the effect of temperature, was determined by examining the residual variation in $P_{m}^{c h}$ (i.e. the observed

The decline in $F_{v} C h I^{-1}$ observed when Sites A and C were occupied for a day was significantly correlated with the mean irradiance in the water column $(\mathrm{p}<$ 0.05 ) in 8 of the 10 sets of observations (Fig 7). The intercepts and slopes differed between sites and between months. The 2 sets of observations in which $F_{v} C h l^{-1}$ was not significantly correlated (June and July value less the value predicted from the relationship of $P_{m}^{\mathrm{chl}}$ with temperature). The temperature-insensitive (i.e. residual) variation was significantly correlated with $I_{\mathrm{av}}\left(\mathrm{p}<0.01, \mathrm{R}^{2}=0.18\right)$. Removing the effect of temperature did not change the nature of the relationship, which was still an inverse trend, nor did it improve the amount of variability in $P_{\mathrm{m}}^{\mathrm{chl}}$ explained by 
$I_{\mathrm{av}}$ (Fig. 8D). The mean irradiance is determined from the transparency of the water column and incident irradiance ( $E q 2$ ), either of which could be responsible for the relationship between $P_{\mathrm{m}}^{\mathrm{chl}}$ and $I_{\mathrm{ar}}$. There was no significant relationship between the temperatureinsensitive variation in $P_{\mathrm{m}}^{\mathrm{chl}}$ and incident irradiance at the time of sampling (midday). Rather, the temperature-insensitive variation was correlated with an index of the transparency of the water column, $z_{\mathrm{eu}}: z_{\mathrm{m}}$, which is the ratio of the depth of the photic zone to the depth of the mixed layer, in this case taken to be the depth of the water column $\left(p<0.05, R^{2}=0.16\right)$. The relationship was fit to a simple exponential and the threshold value of $z_{\mathrm{e} ! 1}: z_{\mathrm{m}}, 2.2$, above which $P_{\mathrm{m}}^{\mathrm{chl}}$ converges on the value at equilibrium, was determined by curve-fitting (Fig. 8E). Those data in the regression in which $z_{\mathrm{eu}}: Z_{\mathrm{m}}$ was greater than 2.2 were for samples taken at all sites in November and at Site B in March, in each of which the water column was stratified and relatively clear. Last, there was a significant relationship between the temperature-insensitive variation in $P_{\mathrm{m}}^{\mathrm{chll}}$ and $\mathrm{F}_{\mathrm{v}} \mathrm{Chl}^{-1}$, the index that describes the proportion of functional PS II reaction centers $\left(\mathrm{p}<0.05, \mathrm{R}^{2}=0.12\right)$. The trend was positive, so that $P_{\mathrm{m}}^{\text {chl }}$ increased as $F_{\mathrm{v}} C h l^{-1}$ rose (Fig. $8 \mathrm{~F}$ ) There was no significant relationship between the midday values of $F_{\mathrm{v}} \mathrm{Chl}^{-1}$ and either the mean irradiance in the water column or with $z_{\mathrm{en}}: z_{\mathrm{m}}$, although within-day variability in $\mathrm{F}_{\mathrm{v}} \mathrm{Chl}^{-1}$ was inversely correlated with the mean irradiance in the water column in 8 of 10 sets of observations (Fig. 7).

\section{Abundance and photosynthetic responses of the microphytobenthos}

The benthic microalgae were abundant and photosynthetically competent, although peak irradiances at the surface of the sediment were very low for all sample periods except November $\left(<150 \mu \mathrm{mol} \mathrm{m} \mathrm{m}^{-2} \mathrm{~s}^{-1}\right.$ in 19

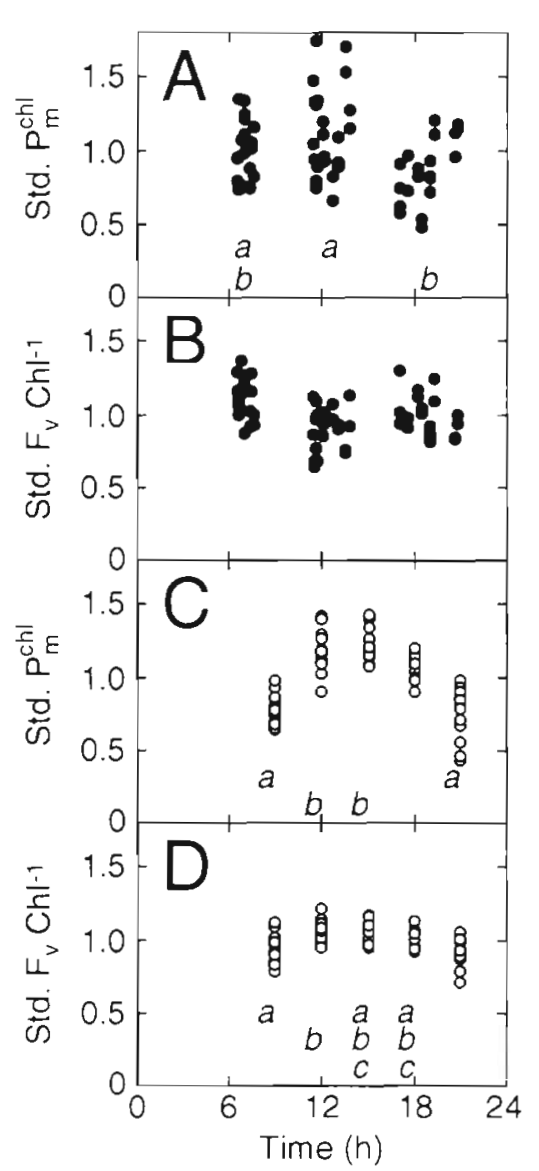

Fig. 6. Dawn-to-dusk variability in standardized values (i.e. normalized to the daily mean of photosynthetic parameters. Standardized values of $\left(A_{1}\right) P_{m}^{\text {th }}$ and $(B) F_{v} C h l^{-1}$ in San Antonio Bay. Standardized values of (C) $P_{\mathrm{m}}^{\mathrm{ch}}$ and (D) $F_{\mathrm{y}} C h l^{-1}$ in Thalassiosira pseudonana. Data for San Antonio Bay (•) were collected at Sites $A$ and $C$ when the site was occupied for a full day. Data for the diatom T. pseudonana $(0)$ are from cultures grown on a $12 \mathrm{~h} \mathrm{light:12} \mathrm{h}$ dark cycle at 8 irradiances between 10 and $900 \mu \mathrm{mol} \mathrm{m}^{-2} \mathrm{~s}^{-1}$. For each period, samples that are not significantly different ( $p<0.05,1$-way ANOVA) are marked with the same letter
Fig. 7. Variation in the fluorescence parameter $\mathrm{F}_{\mathrm{v}} \mathrm{Ch}^{-1}$ with mean irradiance in the water column, $I_{\text {cly }}$, during 10 daylong observations at Site A 10. 口) and Site $C(\bullet, \bullet)$. Data are for mornings $(\mathrm{O}, \bullet)$ and afternoons $(\square, \boldsymbol{a})$ in $(A)$ November, (B) January, (C) March (Site C only), (D) April, (E) June (Site $C$ only), and ( $F$ ) July. The values of $F_{3} \mathrm{ChI}^{-1}$ taken in the morning varied signif $\lrcorner$ cantly with $I_{\text {iv }}(p<0.05)$ in 8 of the 10 observations. There was no significant relationship at Site C in June or July

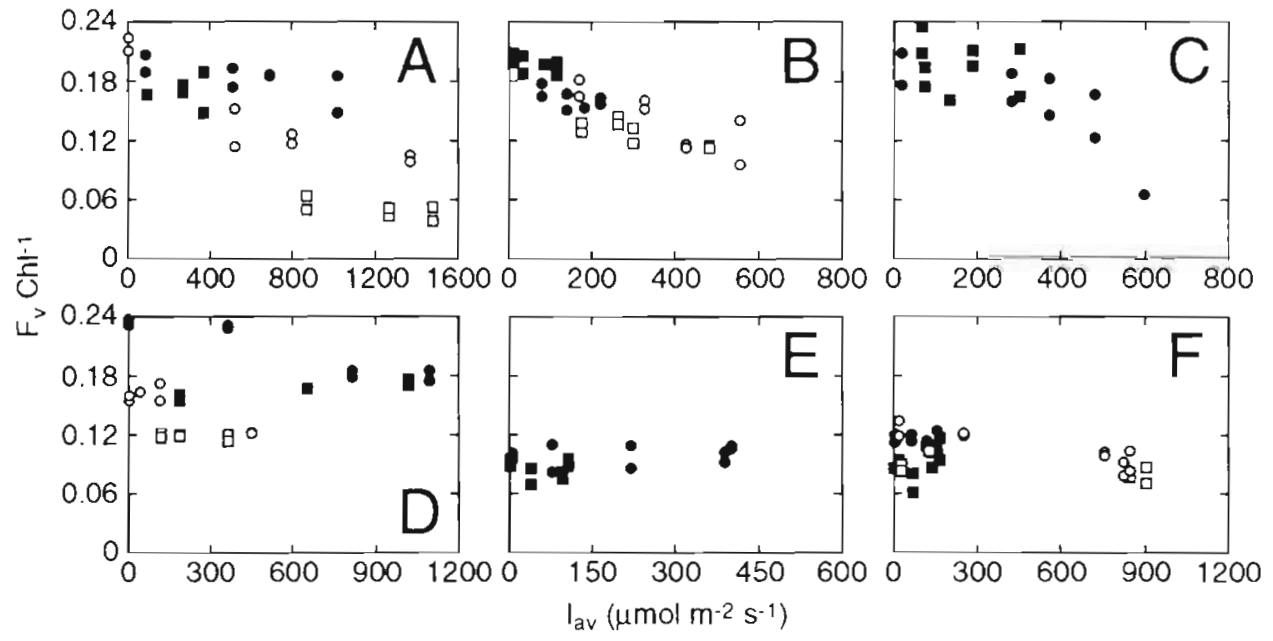



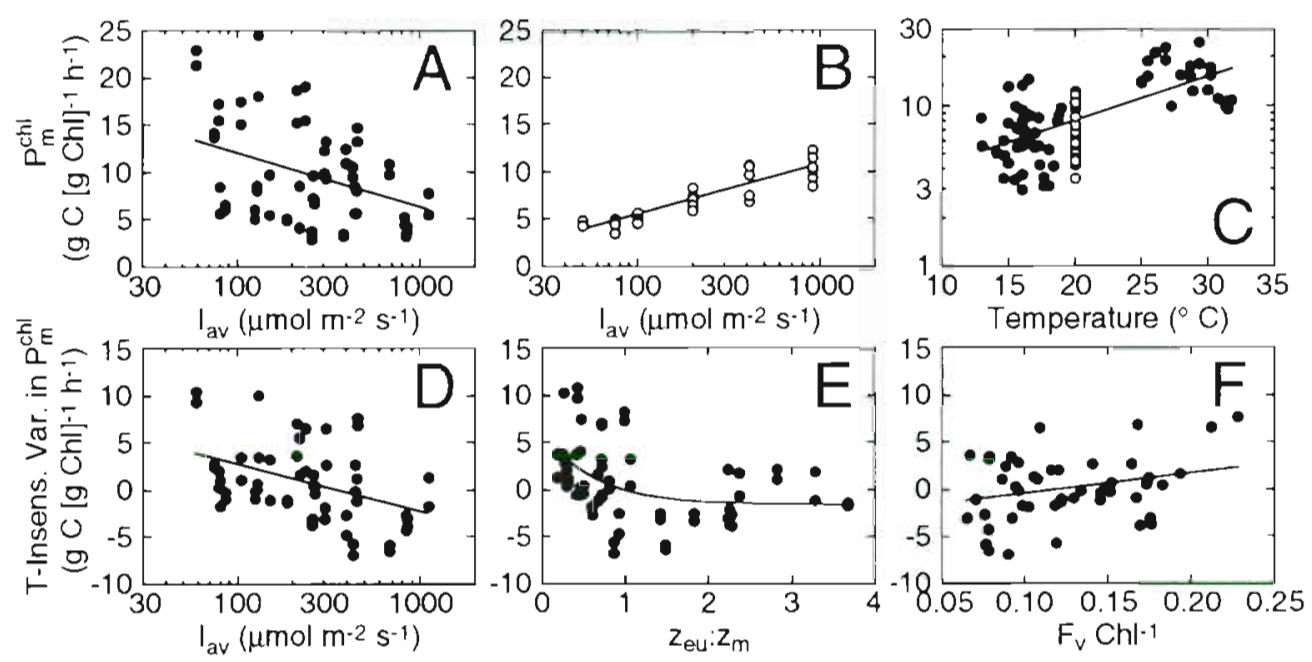

Fig. 8. Variation in the light-saturated rate of photosynthesis, $P_{\mathrm{m}}^{\mathrm{chl}}$, in samples taken at midday in San Antonio Bay and in cultures of the diatom Thalassiosira pseudonana. Cultures were grown on a $12 \mathrm{~h}$ light: $12 \mathrm{~h}$ dark and were sampled 3,6 and $9 \mathrm{~h}$ into the light period. Regression fits are shown on each panel. Linear fits were by Bartlett's Type II regression. (A) $P_{\mathrm{m}}^{\mathrm{chl}}$ versus mean irradiance in the water column, $I_{\mathrm{av}}$, in San Antonjo Bay. $P_{\mathrm{m}}^{\mathrm{chl}}=23.0-5.4 \log \left\{I_{\mathrm{w}}\right)\left(\mathrm{p}<0.05, \mathrm{R}^{2}=0.18\right)$. (B) Pm versus growth irradiance in cultures of $T$. pseudonana. $P_{\mathrm{m}}^{\mathrm{chi}}=-5.2+5.3 \log \left(I_{\mathrm{as}}\right)\left(p<0.001, \mathrm{R}^{2}=0.82\right)$. (C) $P_{\mathrm{m}}^{\text {chi }}$ versus temperature in the water column in San Antonio Bay (data for $T$. pseudonana (O) are shown for comparıson) $\log \left(P_{m}^{\mathrm{chl}}\right)=0.42+0.025 \times$ Temp. $\left(\mathrm{p}<0.001, \mathrm{R}^{2}=0.46\right)$. (D) Temperature-insensitıve variation in $P_{\mathrm{m}}^{c h l}$ versus $I_{\mathrm{av}}$ in San Antonio Bay. Temperature insensitive variation $=11.1-4.4 \log \left(I_{\mathrm{av}}\right)(p<0.01$, $\mathrm{R}^{2}=0.18$ ). Temperature-insensitive variation is (observed-expected), where the expected value is calculated from temperature using the regression in $(\mathrm{C})$. (E) Temperature-insensitive variation in $P_{\mathrm{m}}^{\text {chl }}$ versus $z_{\mathrm{eu}}: z_{\mathrm{m}}$ in San Antonio Bay, where $z_{\mathrm{eu}}: z_{\mathrm{m}}$ is the ratio of the depth of the euphotic zone to the depth of the water column. Temperature-insensitive variation $=8.3 \exp \left(-2.2 \times z_{\mathrm{eu}}: z_{\mathrm{m}}\right)-1.2$ $\left(\mathrm{p}<0.05, \mathrm{R}^{2}=0.16\right)$. (F) Temperature-insensitive variation in $P_{\mathrm{m}}^{\text {chl }}$ versus chlorophyll-specific variable fluorescence in vivo, $F_{\mathrm{v}} C h l^{-1}$, in San Antonio Bay. Temperature-insensitive variation $=-2.6+21.0 \times F_{\mathrm{y}} C h l^{-1}\left(\mathrm{p}<0.05, \mathrm{R}^{2}=0.12\right)$

of 24 cases). Chl a concentrations in the upper 1 to 10 $\mathrm{mm}$ of sediment were low in comparison with other studies (see 'Discussion'). Even so, concentrations in the surficial millimeter $\left(0.5\right.$ to $\left.7.8 \mathrm{~g} \mathrm{~m}^{-3}\right)$ were 40 to 870 times higher (per unit volume) than those in the overlying water In 12 of the 24 comparisons, the upper $10 \mathrm{~mm}$ of the sediment contained as much chl $a$ as the entire overlying water column (Fig. 9) There was no relationship between benthic chl a concentration and the irradiance at the sediment-water interface at the time of sampling. Instead, the abundance of benthic chl a had the same spatial and temporal patterns as the concentration in the water column. The vertical distribution within the sediment varied between sites and sample dates but concentrations at the surface of the benthos were higher than those at $10 \mathrm{~mm}$ in 17 of the 24 profiles (Fig. 9).

Although chl a concentrations at 0 to $1 \mathrm{~mm}$ in the sediment differed from those at 2 to $3 \mathrm{~mm}$ in only 6 of 24 profiles, the photosynthetic responses were consistently different, with lower values of both $P_{\mathrm{m}}^{\text {chl }}$ and $\alpha^{\text {chl }}$ in the 2 to $3 \mathrm{~mm}$ layer. Mean irradiances in the 0 to 1 mm layer were low $\left(<1\right.$ to $65 \mu \mathrm{mol} \mathrm{m}^{-2} \mathrm{~s}^{-1}$ at midday) because of the low irradiance incident on the sediment surface and the very rapid attenuation in the sediment itself (attenuation coefficients of 4.8 to $7.9 \mathrm{~mm}^{-1}$ ). The 2 to $3 \mathrm{~mm}$ layer was under aphotic conditions at all times. There was no significant diel variation in standardized values of $P_{\mathrm{m}}^{\mathrm{chl}}$ and $\alpha^{\text {chl }}$ in the benthic microalgae. As with the suspended assemblage, there was a significant relationship between $P_{\mathrm{m}}^{\mathrm{chl}}$ at midday and water temperature $\left(p<0.05, R^{2}=0.30 ;\right.$ Fig. 10A) The slope was not significantly different $(p<0.05)$ from the trend for the suspended assemblage but the intercept was lower. In both layers of sediment, $P_{\mathrm{m}}^{\mathrm{chl}}$ was highly correlated $(p<0.001)$ with $P_{m}^{\text {chl }}$ in the suspended microalgae (Fig. 10B). The trend and the degree of correlation were both higher for the 0 to $1 \mathrm{~mm}$ layer than the 2 to $3 \mathrm{~mm}$ layer $\left(\mathrm{R}^{2}=0.62\right.$ vs $\left.\mathrm{R}^{2}=0.50\right)$. Because $P_{\mathrm{m}}^{\mathrm{chl}}$ in both assemblages was correlated with temperature, this relationship might be due to the effect of temperature on each population. When the temperature-insensitive variations in $P_{\mathrm{m}}^{\mathrm{chl}}$ were calculated for both the 0 to $1 \mathrm{~mm}$ and 2 to $3 \mathrm{~mm}$ layers, they were significantly correlated with the temperatureinsensitive variation in $P_{\mathrm{m}}^{\mathrm{chl}}$ in the suspended microalgae $\left(p<0.001, R^{2}=0.44\right.$ for 0 to $1 \mathrm{~mm}, R^{2}=0.42$ for 2 to $3 \mathrm{~mm}$; Fig. 10C). Covariation of $P_{\mathrm{m}}^{\mathrm{chl}}$ in both the benthic and suspended assemblages was therefore not due simply to both varying with temperature.

Productivity in the benthos was restricted to the surficial millimeter and was low $i<0.1$ to $11.2 \mathrm{mg} \mathrm{C} \mathrm{m} \mathrm{m}^{-2}$ $\mathrm{h} \%$, on average only $1.6 \%$ of productivity in the water column, although the benthic microalgae were abun- 


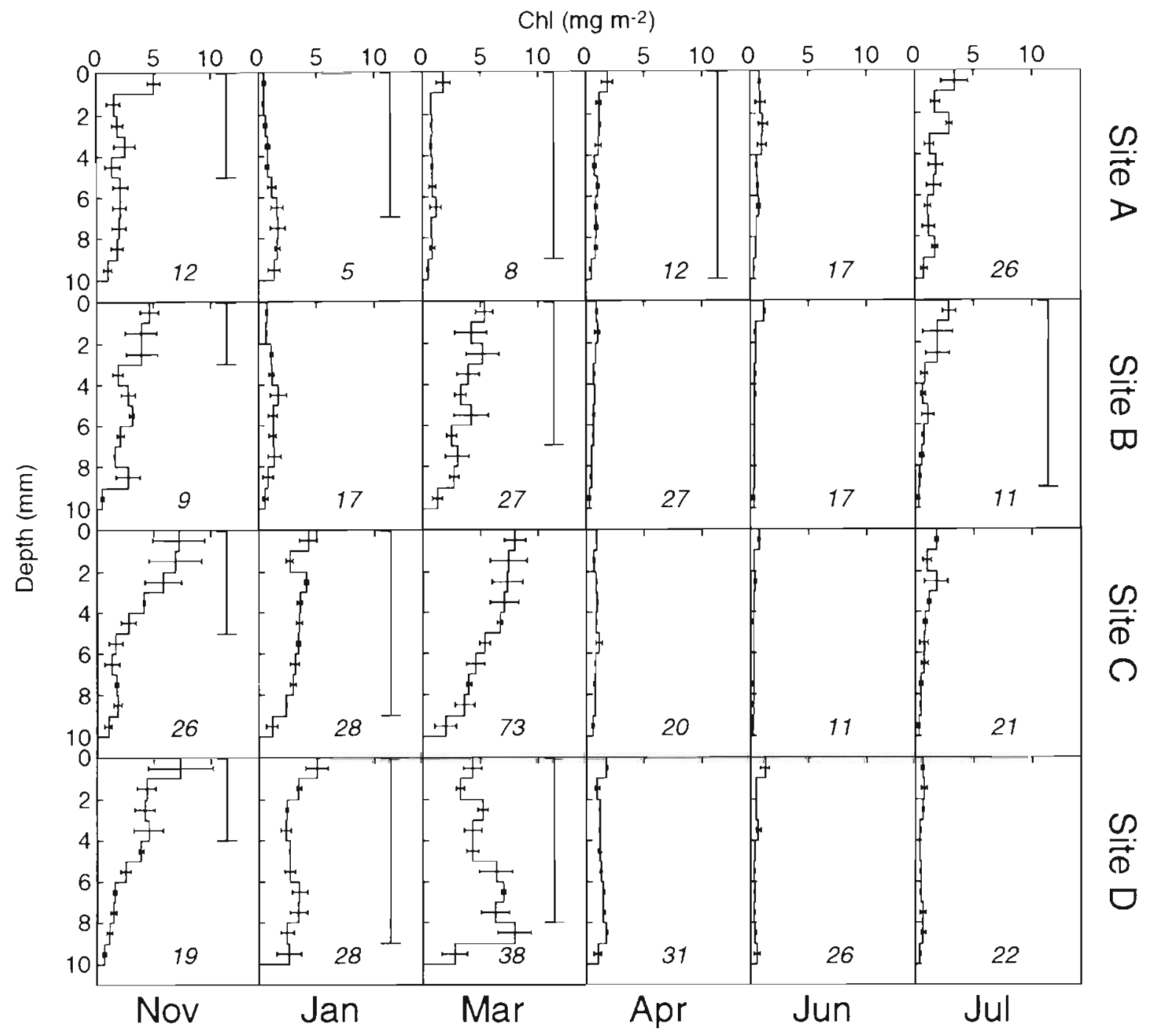

Fig. 9. Profiles of benthic chl $a$ in the upper $10 \mathrm{~mm}$ of sediment by site and date. Error bars are SE of 4 replicates. Data are pre-

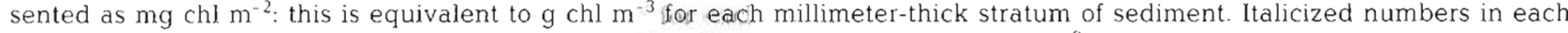

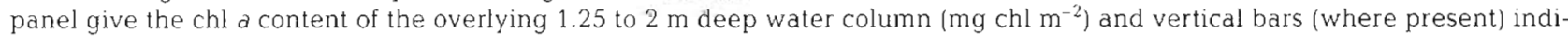
cate the depth of sediment containing an equivalent quantity. Where no bar is shown, the overlying water contained more chl $a$ than the upper $10 \mathrm{~mm}$ of sediment

dant and photosynthetically competent. The technique used to measure attenuation in the sediment likely causes an underestimate of benthic productivity (Kühl \& Jorgensen 1994), but the contribution of the benthos in situ to overall productivity was nonetheless very small.

\section{Within-day variability and covariation of parameters}

Productivity in the water column is determined by irradiance and the abundance and $P$-I responses of the suspended microalgae. The effect of short-term variability in attenuation, chl $a$ and $P-I$ parameters
(Figs. $3 \& 4$ ) on productivity depends on the magnitude and coherence of the changes. This can be illustrated by a simple approximation to Eqs. (5) to (7) proposed by Talling (1957), as re-stated by Platt et al. $(1990)$ :

$$
\Pi(t)=\frac{P_{\mathrm{m}}^{\mathrm{chl}} \cdot C h I}{k} \cdot \ln \left(\frac{2 I_{0}}{I_{k}}\right)
$$

where $I_{k}$ is the saturation parameter of the $P$-I curve, equivalent to $P_{m}^{\mathrm{chl}} / \alpha^{\mathrm{chl}}$. Eq. (9) allows variability in productivity to be partitioned loosely between changes in the abundance and photosynthetic response of the suspended microalgae and the clarity of the water column $\left(P_{\mathrm{m}}^{c h l} \times C h l / k\right)$ and changes imposed externally by the 

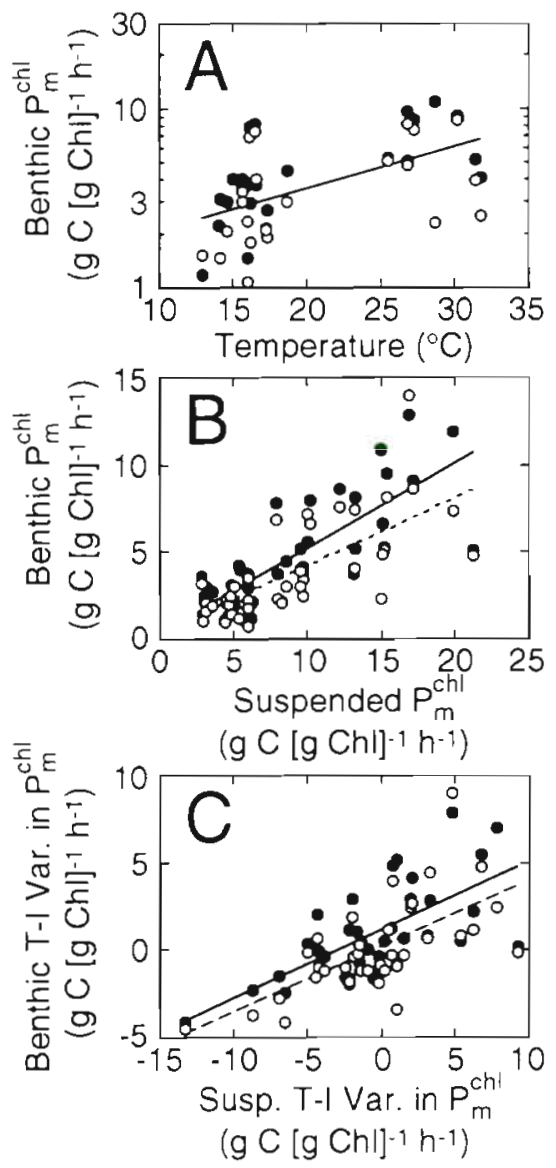

Fig. 10. Variation in $P_{\mathrm{m}}^{\mathrm{chl}}$ in samples taken from the 0 to $1(\bullet)$ and 2 to $3 \mathrm{~mm}(0)$ layers of sediment. Bartlett's Type II regres-

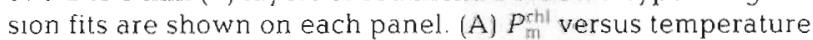
in the water column. The fit is for data for the 0 to 1 and 2 to 3 $\mathrm{mm}$ layers taken at all sites at midday. $\log \left(p_{\mathrm{m}}^{\text {chl }}\right)=0.03+0.026 \times$ Temp $\left(p<0.05, R^{2}=0.30\right)$. (B) $P_{m}^{\text {rhi }}$ in the benthos versus $P_{\mathrm{m}}^{\mathrm{chl}}$ in samples from the surface of the water column. Samples were taken at all sites at dawn, midday and dusk. 0 to $1 \mathrm{~mm}$ (solid line): benthic $P_{\mathrm{m}}^{\mathrm{chl}}=0.3+0.49 \times$ Suspended $P_{\mathrm{m}}^{\mathrm{chl}}(\mathrm{p}<0.001$, $\mathrm{R}^{2}=0.62$ ). 2 to $3 \mathrm{~mm}$ (broken line): benthic $P_{\mathrm{m}}^{\text {chl }}=0.4+0.39 \times$ Suspended $P_{\mathrm{m}}^{\mathrm{chl}}\left(\mathrm{p}<0.001, \mathrm{R}^{2}=0.50\right)$. (C) Temperature-insensitive variation in $P_{m}^{\text {chl }}$ in the benthos versus temperature-insensitive variation in $P_{\mathrm{m}}^{\mathrm{chl}}$ in samples from the surface of the water column. Temperature-insensitive variation is (observed - expected), where the expected value is calculated from temperature using the regression in (A) for the benthos and the regression from Fig. $8 \mathrm{C}$ for the suspended assemblage 0 to $1 \mathrm{~mm}$ (solid line): benthic temperature-insensitive variation $=1.0+$ $0.39 \times$ suspended temperature-insensitive variation $(p<0.001$. $\mathrm{R}^{2}=0.44$ ). 2 to $3 \mathrm{~mm}$ (broken line): benthic temperature-insensitive variation $=0.2+0.37 \times$ suspended temperature-insensituve variation $\left(p<0.001, R^{2}=0.42\right)$

availability of light $\left(I_{0} / I_{k}\right)$. This makes the simplifying assumption that variability in $P$-I response does not result in a change in $I_{k}$. Although $P_{\mathrm{m}}^{\mathrm{chl}}$ and $\alpha^{\mathrm{chl}}$ are correlated, the relationship is not linear, so that $I_{k}$ varies with $P_{\mathrm{m}}^{\mathrm{chl}}$ over much of its range. Changes in $I_{k}$ were small compared to changes in $I_{0}$ (Figs. 3 \& 4) so, as a first approximation, the effects of short-term variability in the biological and physical characteristics of the water column on productivity can be considered in

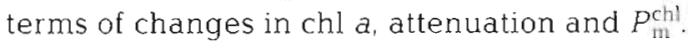

Inspection of Eq. (9) shows that if resuspension were the driving force behind variability, then the coherence in chl $a$, attenuation and $P_{\mathrm{m}}^{\text {chl }}$ would at least partially compensate for the others' effects on $\Pi(t)$ : resuspension of the benthos would result in an increase in attenuation that would offset the increase in chl a and the increase in biomass would also be offset by a decrease in $P_{\mathrm{m}}^{\text {chl }}$ (Fig. 10). Alternately, if advection were the driving force behind short-term variability, changes in attenuation and chl a could be de-coupled and the effect of their variability on $\Pi(t)$ might be additive.

The data collected at Sites $A$ and $C$ are inadequate for cross-spectral analysis and $P_{\mathrm{m} 1 \mathrm{l}}^{\mathrm{chl}}$ was measured only 3 times a day, while chl a and attenuation were measured at hourly to $2 \mathrm{~h}$ intervals. Possible covariation between these parameters was therefore examined using 2 simple comparisons. Covariation of chl $a_{i}$ attenuation and salinity was examined using simple correlation coefficients (Table 3). Salinity is used as a conservative property indicative of different water masses. Changes in salinity were below the threshold of detection in 3 of 4 sets of observations at Site A Examination of the correlation coefficients shows that there is a significant $(p<0.05)$ positive relationship between chl $a$ and attenuation in only 2 of 12 cases and a significant negative correlation in 1. In contrast, there was a significant correlation between chl $a$ and salinity in 3 of 9 cases and a significant correlation between attenuation and salinity in 4 . The opposed correlation of chl $a$ and attenuation with salinity in 2 cases and the negative correlation of chl a with attenuation in 1 case suggests that advection is responsible for some of the variation observed. Equally, the positive correlation of chl $a$ with attenuation in 2 cases and the covariation of chl $a$ and attenuation with salinity in a third are consistent with resuspension.

A second test for covariation in the biological and physical parameters that determine productivity is based on the relationship of productivity to $P_{\mathrm{m}}^{\mathrm{chl}}, \mathrm{chl} a$ and the attenuation coefficient (Eq. 9). The value of a composite parameter, $M$, can be calculated for each of the 10 samples series on which all 3 parameters were measured over the course of a day:

$$
M=\frac{p_{\mathrm{m}}^{\mathrm{chl}} \cdot C h l}{k}
$$

The observed coefficient of variation in $M_{1} C V_{\text {obs }}$ can be compared to an expected coefficient of variation, $C V_{\text {exp }}$, calculated on the assumption that there is 
no covariation between its 3 constituent parameters. If $C V_{\text {obs }}$ and $C V_{\text {exp }}$ are significantly different, then there must be some covariation in the observed changes in $P_{\mathrm{ml}}^{\mathrm{chl}}$, chl a and attenuation. The observed coefficient of variation can be calculated as

$$
C V_{\text {obs }}=\frac{\sigma_{M}}{\bar{x}_{M l}}
$$

where $\sigma_{M}$ is the standard deviation and $\bar{X}_{M}$ is the mean of the calculated values of $M$. There are 6 values per day for 8 of the observations (surface and bottom samples taken at dawn, midday and dusk) and 8 for the remaining 2 (surface and bottom samples taken at midday, dusk, dawn and midday).

Each value of $C V_{\text {obs }}$ is compared with a value, $C V_{\text {exp }}$, that is calculated on the assumption that there is no covariation in $P_{\mathrm{m}}^{\mathrm{chl}}$, chl $a$ and attenuation:

$$
C V_{\exp }=\frac{\sigma_{\bar{M}}}{\bar{M}}
$$

where $\sigma_{\bar{M}}$ and $\bar{M}$ are an aggregate standard deviation and mean derived from the means and standard deviations in $P_{\mathrm{m}}^{\mathrm{chl}}$, chl $a$ and attenuation within each sample series. For each day, the aggregate mean value, $\bar{M}$, is

$$
\bar{M}=\frac{\bar{x}_{p m l} \cdot \bar{x}_{C h l}}{\bar{x}_{k}}
$$

The aggregate standard deviation, $\sigma_{\bar{M}}$, can be derived from the mean and variance of each of the 3 parameters, $P_{\mathrm{ml}}^{\mathrm{chl}}, \mathrm{Chl}$ and $k$, and 3 average cross-terms that describe covariation in each pair (Bevington 1969):

$$
\begin{aligned}
\frac{\sigma_{\bar{M}}^{2}}{\bar{M}^{2}}= & \frac{\sigma_{P_{m}^{c h l}}^{2}}{\bar{x}_{P_{m}^{c h l}}^{2}}+\frac{\sigma_{C h l}^{2}}{\bar{x}_{C h l}^{2}}+\frac{\sigma_{k}^{2}}{\bar{x}_{k}^{2}}+2 \frac{\sigma_{P_{m}^{c h l}}^{2} C h l}{P_{m}^{c h l} \cdot C h l} \\
& -2 \frac{\sigma_{P_{m}^{2} k}^{2} k}{P_{m}^{c h l} \cdot k}-2 \frac{\sigma_{C h l \cdot k}^{2}}{C h l \cdot k}
\end{aligned}
$$

where $\sigma$ is the standard deviation and $\bar{x}$ the mean value of each parameter. If changes in $P_{\mathrm{m}}^{\mathrm{chl}}, C h l$ and $k$ are independent of each other, the cross-terms tend to zero and Eq. (14) reduces to

$$
\frac{\sigma_{\bar{M}}^{2}}{\bar{M}^{2}}=\frac{\sigma_{P \text { ml }}^{2}}{\bar{X}_{P_{i n l}^{2}}^{2}}+\frac{\sigma_{C h l}^{2}}{\bar{X}_{C h l}^{2}}+\frac{\sigma_{k}^{2}}{\bar{X}_{k}^{2}}
$$

Substituting Eqs. (13) and (15) into Eq. (12), the expected coefficient of variation is therefore
Table 3. Pearson correlation coefficients for multiple correlations of daily variations in $\mathrm{chl}$ a concentration $(\mathrm{Ch})$ ), attenuation coefficient $(k)$ and salinity $(S)$. Cor-

\begin{tabular}{|c|c|c|c|c|c|c|}
\hline \multicolumn{2}{|c|}{ Site } & \multirow{2}{*}{$\begin{array}{c}\text { Month } \\
\text { Nov }\end{array}$} & \multirow{2}{*}{$\begin{array}{c}\text { Svs Chl } \\
0.834^{\circ}\end{array}$} & \multirow{2}{*}{$\begin{array}{l}S v s k \\
0.104\end{array}$} & \multirow{2}{*}{$\begin{array}{c}\text { Chlvs } k \\
0.123\end{array}$} & \multirow{2}{*}{$\frac{n}{7}$} \\
\hline A & Surface & & & & & \\
\hline & Bottom & Nov & 0.163 & $0.755^{\circ}$ & 0.297 & 7 \\
\hline & & Jan & & & $0.851^{\cdots}$ & 13 \\
\hline & & Apr & & & -0.314 & 14 \\
\hline & & Jul & & & $-0.651^{\cdots}$ & 16 \\
\hline \multirow[t]{7}{*}{ C } & Surface & Nov & 0.460 & 0.007 & 0.334 & 7 \\
\hline & Bottom & Nov & 0.362 & 0.247 & 0.624 & 7 \\
\hline & & Jan & $-0.581 \cdots$ & $0.632 \cdots$ & -0.101 & 16 \\
\hline & & Mar & $0.392^{\circ}$ & $0.709 \cdots$ & 0.321 & 28 \\
\hline & & Apr & -0.098 & 0.185 & -0.244 & 11 \\
\hline & & Jun & -0.206 & 0.213 & $0.507 \cdots$ & 17 \\
\hline & & Jul & $-0.845 \cdots$ & $0.774 \cdots$ & -0.442 & 16 \\
\hline
\end{tabular}
in of chl a and attenuation with salinity are omitted for Site $A$ sensitivity of the conductivity probe. Data for surface and bottom water are combined except for data collected in November, where there was a surface to ce in salinity of 6 to 9 PSU at both sites. $n$ is number of observations. $p<0.05, \cdots p<0.01, \cdots p<0001$

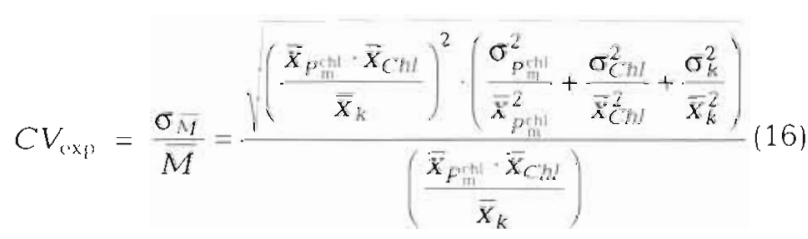

Values of $C V_{\text {exp }}$ and $C V_{\text {obs }}$ were calculated for each of the 10 day-long observations. The observed coefficients of variation were significantly lower than the coefficients of variation expected on the basis of independent changes in $P_{\mathrm{m}}^{\mathrm{chl}}$, chl $a$ and attenuation $(\mathrm{p}<$ 0.001 , paired $t$-test; Fig. 11), indicating that changes in the constituent parameters of $M$ were compensatory. The lower-than-expected variation indicates that covariation between $P_{\mathrm{m}}^{\text {chl }}$ and attenuation or between chl $a$ and attenuation outweighed covariation between $P_{\mathrm{m}}^{\mathrm{chl}}$ and chl a (see Eq. 14).

\section{Estimates of daily productivity}

Daily areal productivity, $\prod_{\text {day }}$, was calculated by integrating between estimates of $\Pi(t)$ (Eq. 8) from dawn to dusk in 8 cases and from noon to noon in 2 others. Estimates of daily productivity were 0.13 to $2.47 \mathrm{~g}$ $\mathrm{C} \mathrm{m}^{-2} \mathrm{~d}^{-1}$ in the water column and $<0.001$ to $0.09 \mathrm{~g} \mathrm{C}$ $\mathrm{m}^{-2} \mathrm{~d}^{-1}$ in the benthos. Daily productivity in the benthos averaged $1.6 \%$ of that in the water column. There was a significant relationship ( $p<0.05)$ between daily productivity and the composite parameter BZI (Cole \& Cloern 1984), which is the product of the chl a concentration $(C h l)$, the depth of the euphotic zone $\left(z_{\text {eu }}\right)$, and 


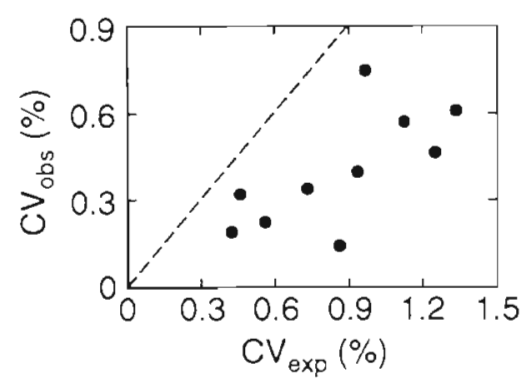

Fig. 11. Observed within-day variatıon in the composite parameter $M\left(=P_{\mathrm{m}}^{\mathrm{chl}} \times C h l / k\right), C V_{\text {otw }}$ versus the variation expected on the assumption of independent changes in $P_{\mathrm{ml}}^{\mathrm{chl}}, C h l$ and $k_{\text {, }}$ $C V_{\text {exp }}$. Data were collected at the surface and bottom of the water column at Sites $\mathrm{A}$ and $\mathrm{C}$ at dawn, midday and dusk or at midday, dusk, dawn and midday. Dotted line shows the $1: 1$ relationship

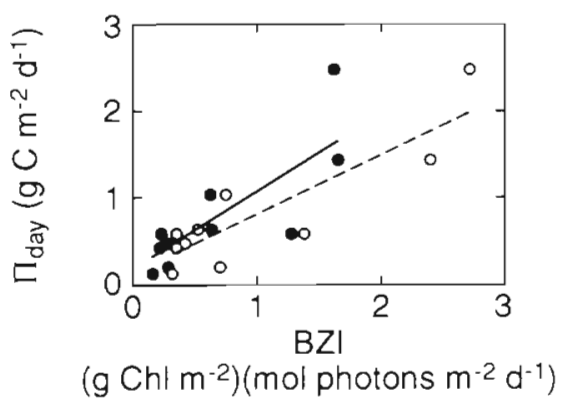

Fig. 12. Daily productivity, $\prod_{\text {day }}$ versus the composite parameter BZl at Sites A and C, San Antomo Bay. Dally productivlty was calculated by interpolation between rates estimated from samples taken every 1 to $2 \mathrm{~h}$. The composite parameter is the product of the chl a concentration in the euphotic zone $\left(C h l \times z_{r u}\right)$ and daily incident irradiance, $I_{\mathrm{InI}}$. Estimates were based on the values of $C h l \times z_{e \mu}$ measured at midday ( solid line) or on the daily average values of $C h I \times z_{e u}(0$, broken line). The lines are Type II regressions. Midday values: $\prod_{i d,}=$ $0.20+0.61 \times B Z I\left(p<0.05, R^{2}=0.75\right)$. Averaged values: $\Pi_{\text {didy }}=$ $0.20+0.85 \times B Z I\left(\mathrm{p}<0.05, \mathrm{R}^{2}=0.72\right)$. The $95 \%$ confidence limits for the slopes were 0.33 and 0.99 (midday values) and 0.26 and 1.04 (averaged values)

total incident irradiance $\left(I_{\text {in }}\right)$. The relationship was significant whether the estimate of $B Z I$ was based on the concentration of chl a in the euphotic zone $\left(C h l \times z_{\mathrm{eu}}\right)$ averaged over the course of the day or on the midday values alone (Fig. 12). The slope of the relationship was $0.88(95 \%$ confidence limits 0.26 and 1.04$)$ for the averaged values and 0.67 (95\% confidence limits 0.33 and 0.99 ) for the midday values. Accounting for the full variability in chl a and attenuation did not improve the amount of variability in productivity explained by the composite parameter

The BZI model lacks any description of the photosynthetic responses of the microalgae but could account for $75 \%$ of the variability in daily productivity, albeit on a very small set of samples. Comparison of predictions based on midday values of chl $a$ and the attenuation coefficient with those based on full withinday variability show that daily productivity can be predicted by extrapolation from the midday value. The accuracy of the estimate can be improved by inclusion of the $P-I$ response. We examine 3 very simple formulations for calculating daily productivity, based on a single observation of microalgal biomass and $P-I$ response. Daily productivity extrapolated from areal productivity at midday, $\prod_{\dot{d} ;,}^{-}$, was compared with daily productivity calculated from Eqs. (5) to (8). $\prod_{\text {day. }}$ using 3 simple models. The input for each model was the midday estimate of productivity, $\prod_{\text {rioon }}$ supplemented with an increasingly detailed record of irradiance.

The first model does not incorporate a continuous record of irradiance and is the product of $\prod_{\text {noon }}$ and the number of hours of daylight, $D$ (Marshall et al. 1971)

$$
\text { Model } 1 \quad \Pi_{\text {dav }}^{*}=\Pi_{\text {noon }} D
$$

This assumes that the mean rate of areal photosynthesis does not vary over the course of the day. The second model is a modification of Model 1 , in which $\prod_{\text {roon }}$ is weighted by mean incident irradiance over the day (Leach 1970):

$$
\text { Model } 2 \quad \Pi_{\text {day }}^{*}=\Pi_{\text {noon }} \cdot D \cdot\left(\frac{I_{\mathrm{d}}}{I_{\mathrm{n}}}\right)
$$

where $I_{\mathrm{n}}$ is incident irradiance at noon, the time of sampling, and $I_{\mathrm{d}}$ is the mean irradiance over the day This assumes that there is a linear relationship between $\Pi_{I(l)}$ and $I_{0}$ (however, see Fig. 5). The third model incorporates the diel variability in irradiance:

$$
\text { Model } 3 \quad \Pi_{\text {day }}^{*}=\sum_{t=0}^{t=D} \Pi_{[(t)} \cdot \Delta t
$$

where values of $\prod_{/(t\}}$ were calculated according to Eqs. (5) to (8) using the single, midday measurement of chl $a_{1}$ attenuation and P-I parameters. Only $I_{0}$ was permitted to vary.

The output of the 3 models was compared to the observed value of daily production, $\prod_{\text {daw }}$ calculated from Eqs. (5) to (8) in which full variability of chl $a_{1} P-I$ response, attenuation and irradiance is taken into account (Table 4). The mean errors for Models 1, 2 and 3 were 62,28 and $27 \%$, respectively. The 3 models can be ranked in order of the accuracy of prediction (i.e. the slope of the relationship and the magnitude and distribution of errors) in the following order: Model $3>$ Model $2>$ Model 1.

\section{DISCUSSION}

The waters of San Antonio Bay are both turbid and productive. The average and minimum depths of the 
euphotic zone $(1.1$ and $0.3 \mathrm{~m})$ rank it with the most turbid of 26 bays and estuaries reviewed by Cloern (1987). Even so, the mean irradiance in the shallow water column was comparatively high, exceeding $400 \mu \mathrm{mol} \mathrm{m} \mathrm{m}^{-2} \mathrm{~s}^{-1}$ in half of the 28 samples taken at midday. Suspended chl a concentrations were in the midrange of 39 estuarine systems reviewed by Day et al. (1989) but daily productivity was comparable to that in deeper and clearer waters, such as the Chesapeake, Delaware and Narragansett bays (eastern coast, USA), and the estuaries of the Fraser (Canada), Hudson (USA) and St. Lawrence rivers (reviewed by Pennock \& Sharp 1986, Day et al. 1989). The high productivity is due, in part, to the microalgae maintaining high lightsaturated rates of photosynthesis in spite of the turbid conditions characteristic of the bay.

The water column in San Antonio Bay was also characterized by a high degree of short-term (hours) variability in both physical and biological characteristics (turbidity and microalgal biomass and photosynthetic response). On the same time-scale, productivity was less variable than might be expected because of coherence in the changes. A practical consequence of this is that reasonable estimates of integrated daily productivity can be obtained by extrapolation from an estimate of productivity at midday. We argue that the coherence is due to parallel resuspension of sediment and benthic microalgae and to covariation of lightsaturated rates of photosynthesis and turbidity, because high turbidity reduces the likelihood of photoinhibition.

\section{Photosynthetic responses of the suspended microalgae}

Light-saturated rates of photosynthesis, $P_{m}^{c h l}$, in San Antonio Bay were comparable to those in much clearer waters, such as the Hudson River estuary and New
York Bight (Malone 1977, Malone \& Neale 1981) and the Gulf of Mexico (Lohrenz et al. 1994, J. Cullen unpubl.). Similar values have also been measured in the Neuse River estuary (North Carolina, USA) (Boyer et al. 1993), in which the range of $z_{\text {eu }}: z_{\mathrm{m}}$ was comparable (ca 0.5 to 1.6 ) to that in San Antonio Bay, although the water column was deeper $(2.2$ to $4.3 \mathrm{~m}$ ). In all but the Neuse, much of the variability in $P_{\mathrm{m}}^{\mathrm{chl}}$ could be explained by temperature. The $Q_{10}$ of 1.8 reported here is comparable to values measured over seasonal time-scales by other investigators (Eppley 1972, Harris \& Piccinin 1977, Malone 1977. Harrison \& Platt 1980, Malone \& Neale 1981), although temperature could explain only $46 \%$ of the variability in $\log \left(P_{\mathrm{m}}^{\mathrm{ch}}\right)$.

The decline in midday values of $P_{m}^{c h 1}$ as mean irradiance in the water column increases, which is robust after the data are corrected for the effect of temperature, was not expected on the basis of the relationship between $P_{\mathrm{m}}^{\mathrm{chl}}$ and growth irradiance in cultures (Geider 1993), as typified by the response of the diatom Thalassiosira pseudonana. The trend was due to variation of $P_{\mathrm{m}}^{\mathrm{chl}}$ with turbidity. We consider 3 mechanisms, which are not mutually exclusive, that might be responsible for the relationship. These are (1) sizedependent variations in photosynthetic response, (2) acclimation to rapidly fluctuating irradiance, and (3) an effect of photoinhibition.

The first possible explanation is based on differences in the photosynthetic responses of large and small cells. Net plankton $(>20 \mu \mathrm{m})$ tend to have lower lightsaturated rates of photosynthesis than nanoplankton (Malone \& Neale 1981). Where the reverse has been shown (Malone 1977), the net plankton was dominated by small chain-forming species. The relationship between temperature-independent variation in $P_{\mathrm{m}}^{\mathrm{ch}}$ and turbidity might therefore be due to a prevalence of small cells in turbid waters. Although large cells will sink out of the water column more rapidly than unattached small cells, the benthic microalgae most likely

Table 4. Regression coefficients of daily productivity predicted from Eqs. (17) to (19), $\prod_{\mathrm{d}_{\mathrm{d}} \mathrm{r}}$, on observed values, $\prod_{\mathrm{daw}}$, calculated from Eqs. (5) to (8) $(n=10)$. The slopes are reported as estımates (SE shown in parentheses). Errors are reported as range (mean, $S E$ in parentheses) and are in absolute units $\left(\mathrm{g} \mathrm{C} \mathrm{m}^{-2} \mathrm{~d}^{-1}\right)$. None of the intercepts were significantly different from zero ( $\left.\mathrm{p}<0.05\right)$. $\prod_{\text {day }}$ ranged from 0.13 to $2.47 \mathrm{~g} \mathrm{C} \mathrm{m}^{-2} \mathrm{~d}^{-1}$

\begin{tabular}{|ccccc|}
\hline & & Slope & $\mathrm{R}^{2}$ & Errors \\
\hline 1 & $\Pi_{\text {day }}=\prod_{\text {noon }} \cdot D$ & $1.35(0.17)$ & 0.88 & -0.05 to $1.44(0.39,1.63)$ \\
3 & $\Pi_{\text {day }}^{*}=\prod_{\text {noon }} \cdot D \cdot\left(\frac{I_{\mathrm{d}}}{I_{\mathrm{n}}}\right)$ & $0.82(0.14)$ & 0.82 & -0.70 to $0.44(0.05,0.15)$ \\
& $\Pi_{\text {day }}=\sum_{t=0}^{t=D} \Pi_{l(t)} \cdot \Delta t$ & $1.06(0.10)$ & 0.93 & -0.12 to $0.65(0.11,0.23)$ \\
\hline
\end{tabular}


to be resuspended and then settle out of the water column are small cells associated with silt particles (de Jonge \& van den Bergs 1987, Delgado et al. 1991). However, the benthic assemblages had lower light-saturated rates of photosynthesis than the suspended assemblages (Fig. 10), so resuspension should cause a decrease rather than an increase in $P_{\mathrm{m}}^{\mathrm{chl}}$ as turbidity increases.

A second possible explanation for the observed trend of temperature-independent changes in $P_{\mathrm{m}}^{\mathrm{chl}}$ with turbidity is that the cells in the water column are acclimated to a fluctuating light regime. Laboratory studies in which microalgae have been subjected to simulated mixing are available for 5 species from 3 classes. The algae were subjected to regimes in which either mean irradiance or the peak irradiance varied. Except for the response of the chlorophyte Chlorella pyrenoidosa (Kroon et al. 1992), $P_{\mathrm{m}}^{\text {chl }}$ fell when mean irradiance declined but peak irradiances did not change, and rose when the peak irradiance increased and the mean irradiance did not vary (Marra 1978a, Kromkamp \& Limbeek 1993, Ibelings et al. 1994). Similar trends have been observed in some estuarine habitats. Vincent et al. (1994) concluded that phytoplankton in the mixed layer of the St. Lawrence were acclimated to peak rather than mean irradiance and assemblages from the New York Bight (Malone 1977) and Vineyard Sound, Massachusetts (USA) (Glibert et al. 1985), had values of $P_{\mathrm{m}}^{\mathrm{chl}}$ that were higher than expected from the relationship with temperature when the water column was well-mixed. These results are broadly consistent with the responses of microalgae grown under stable illumination, in which $P_{m}^{c h l}$ increases with growth irradiance (Geider 1993).

The trend in $P_{m}^{c h i}$ with mean irradiance presented here is the opposite of the acclimative responses described in the laboratory studies. This could be because the highest frequency of change employed in these studies, corresponding to a cycle through the euphotic zone in an hour, is much slower than the transit-time of minutes characteristic of a turbid and wellmixed body of water (MacIntyre 1993). There is also a mismatch in time-scales that make it unlikely that the trend in $P_{\mathrm{m}}^{\mathrm{chl}}$ is due to acclimation: kinetic studies with cultures (Post et al. 1984, Cullen \& Lewis 1988, Kromkamp \& Limbeek 1993) indicate that acclimative changes in $P_{\mathrm{mi}}^{\mathrm{chi}}$ to a change in irradiance are slower than the time-scale on which turbidity varies in San Antonio Bay. An acclimative response to a fluctuating light regime may be responsible for the generally high values of $P_{\mathrm{m}}^{\mathrm{chl}}$, but is unlikely to account for the decline in $P_{\mathrm{m}}^{\mathrm{chl}}$ as the water column becomes clearer and more stable.

A third explanation for the trend in temperatureindependent changes in $P_{\mathrm{m}}^{\mathrm{chl}}$ with turbidity is that high turbidity and rapid mixing protect the suspended microalgae from photoinhibition (i.e. damage to photosynthetic reaction centers). Photoinhibition occurs when the rate of excitation at the reaction centers exceeds the rate at which absorbed energy can be dissipated, either by photosynthesis or by a non-photosynthetic mechanism such as the xanthophyll cycle (Demers et al. 1991, Olaizola \& Yamamoto 1994) or the Mehler reaction (Kana 1992). This is most likely to occur when phytoplankton acclimated to relatively low irradiance are stranded at high irradiance, as occurs when mixing is reduced (Vincent et al. 1984, Elser \& Kimmel 1985, Neale \& Richerson 1987). Surface photoinhibition is commonly seen in the fixed-depth incubations that are frequently used to estimate productivity. The onset of photoinhibition can be rapid, occurring in <30 min (Neale \& Richerson 1987) and photoinhibitory irradiances may extend well into the water column. In $4 \mathrm{~h}$ incubations in the Neuse river estuary, even photosynthesis at $58 \%$ of surface irradiance was depressed relative to photosynthesis at $35 \%$ of surface irradiance (Mallin \& Paerl 1992). The 35\% light level corresponded to a depth of $1.1 \mathrm{~m}$ in a $3.4 \mathrm{~m}$ water column. Imposing some degree of mixing by cycling incubated bottles through a light gradient can alleviate the photoinhibition (Marra 1978a, b, Randall \& Day 1987, Mallin \& Paerl 1992) but none of the comparisons of moving-and fixed-bottle incubations have demonstrated that photoinhibition had been eliminated by mixing, only that it had been reduced relative to stationary controls.

In San Antonio Bay, the entire water column appears to be photoinhibited under the natural mixing regime. The basis for this argument is the decline in $\mathrm{F}_{\mathrm{v}} \mathrm{Chl}^{-1}$ (an index of the proportion of functional reaction centers) observed at high irradiance and the trend between $F_{v} \mathrm{Chl}^{-1}$ and the temperature-insensitive variation in $P_{\mathrm{m}}^{\mathrm{chl}}$. A decline in $F_{\mathrm{v}} C h l^{-1}$ after cells have been subjected to high light stress has been correlated with a reduction in light-limited and light-saturated rates of photosynthesis (Davis 1986, Neale \& Richerson 1987. Neale et al. 1989, Leverenz 1990), although there may be a reduction in $\alpha^{\text {thl }}$ and $F_{v} \mathrm{Chl}^{-1}$ without a reduction in $P_{\mathrm{m}}^{\mathrm{chl}}$ (Cullen et al. 1988). The surtace inhubition of modeled photosynthesis at Site A in November, January and April and at Site $C$ in November and April (Figs $3 \& 4$ ) will occur only if the time-scale of mixing in San Antonio Bay is slower than the 20 min over which the $P$ - $I$ curves were measured (Davis 1986). This is potential photoinhibition, which is characterized by a fall-of in photosynthetic rates at high irradiance during the $P$ - $I$ incubation and a consequent surface depression in modeled photosynthesis. Photoinhibition. that has occurred in situ prior to the incubation is characterized by a reduction in $F_{\mathrm{s}} C h l^{-1}$ and $P_{\mathrm{m}}^{\mathrm{chi}}$ and little, 
if any, fall-off (Vincent et al. 1984, Neale \& Richerson 1987, Henley 1993).

In 8 of 10 cases where the water column in San Antonio Bay was monitored through the day, there was a decline in $F_{\mathrm{v}} \mathrm{Chl}^{-1}$ that was correlated with the mean irradiance in the water column. In 5 of the 7 cases where the comparison could be made, there was a hysteresis in the afternoon recovery (Fig. 7). This is the pattern of photoinhibition described by Neale \& Richerson (1987). The midday decline was sufficiently persistent that it was detectable when each day's data were standardized and pooled: there was a decline during the morning and a partial recovery in the afternoon (Fig. 6). The same pattern of within-day variability could be seen in 3 of 4 between-day comparisons where changes in the mean irradiance in the water column at midday were mirrored by opposing changes in $F_{v} \mathrm{Chl}^{-1}$ (Fig. 5). The depression in $\mathrm{F}_{\mathrm{v}} \mathrm{Chl}^{-1}$ at high irradiance is unlikely to be due to quenching of fluorescence by inter-conversion of the photoprotective xanthophylls diatoxanthin and diadinoxanthin (Demers et al. 1991, Olaizola and Yamamoto 1994). Quenching by diatoxanthin after an imposed light stress can persist for 30 min or more in darkness, the pre-treatment for measuring $F_{v} C l^{-1}$ in this study, but only after the reaction centers have endured photoinhibitory damage (Arsalane et al. 1994)

Variations in the photosynthetic responses of the suspended microalgae were also consistent with photoinhibition. Both the light-limited and light-saturated rates of photosynthesis ( $\alpha^{\text {chl }}$ and $P_{\mathrm{m}}^{\mathrm{chl}}$ ) varied with $F_{v} C h l^{-1}$ and varied inversely with the mean irradiance in the water column between days at the same site (Fig. 5) and between months and sites (Table 2, Fig. 8). The temperature-insensitive variation in $P_{\mathrm{m}}^{\mathrm{chl}}$ was also correlated with $F_{v} \mathrm{Chl}^{-1}$ and mean irradiance between months and sites (Fig. 8). It is possible that the lack of a diel maximum in $P_{\mathrm{ml}}^{\mathrm{chl}}$ in the natural assemblage, coincident with a minimum in $F_{v} C h l^{-1}$ was partially due to photoinhibition (cf. Cullen et al. 1992). Diel changes in $P_{m}^{c h l}$ and $F_{v} C_{h l}^{-1}$ in San Antonio Bay were distinct from those in cultures of the diatom Thalassiosira pseudonana (Fig. 6). Samples from the bay did not show the pronounced peak in $P_{\mathrm{m}}^{\mathrm{chl}}$ that coincided with a peak in $F_{v} \mathrm{Chl}^{-1}$ in $T$ pseudonana and which have been reported in other natural assemblages (Harding et al. 1982, 1987). The $P$-I curves of the natural samples were also flatter than those in the cultures, as measured by the index $P_{\mathrm{m}}^{\mathrm{chl} /} / P_{\mathrm{m}}^{\mathrm{chl}}$, a characteristic of photoinhition (Neale \& Richerson 1987, Henley 1993). However, a damping of the diel rhythm in $P_{m}^{\mathrm{chl}}$ also occurs when cells are grown in fluctuating light fields (Kroon et al. 1992, Ibelings et al. 1994).

The relationships between mean irradiance, $P_{\mathrm{m}}^{\mathrm{chl}}$ and $F_{v} C l^{-1}$ can be ascribed to changes in turbidity that lead to changes in the mean irradiance in the water column. The relationship between the temperatureinsensitive variation in $P_{\mathrm{m}}^{\mathrm{chl}}$ and $z_{\mathrm{eu}}: Z_{\mathrm{m}}$ can therefore be interpreted as an increase in the degree of photoinhibition (a fall in the proportion of functional reaction centers and subsequently in $P_{\mathrm{mi}}^{\mathrm{chl}}$ ) as the water column becomes more stable and less turbid and the entrained microalgae are exposed to higher irradiances and slower mixing through the light gradient. While maintaining a high light-saturated rate of photosynthesis may be an adaptive trait, in that it allows opportunistic use of high ir radiance during episodic exposure, it may also have a photoprotective role by reducing the range of conditions under which photoinhibition is likely to occur. We argue that the high values of $P_{\mathrm{m}}^{\text {chl }}$ measured in San Antonio Bay are an acclimative response to episodic high irradiances, possibly with a secondary photoprotective role, but that the trend of $p_{\mathrm{m}}^{\mathrm{chl}}$ with mean irradiance is due to an increasing degree of photoinhibition throughout the water column when turbidity declines.

\section{Short-term variability in the water column and resuspension}

Short-term (hours) variability of algal biomass in estuaries may be due to advection of patchily-distributed assemblages, resuspension of benthic microalgae or changes in the balance between algal growth and grazing. If resuspension dominates, an increase in turbidity will be offset by an increase in the abundance of microalgae in the water column. Covariance in chl a and turbidity has been reported in the shallow waters of other estuaries (Demers et al. 1987, Cloern et al. 1989, Powell et al. 1989, Litaker et al. 1993).

Concentrations of benthic chl $a$ in San Antonio Bay, although among the lowest reported (Macintyre et al. 1996) are very high relative to concentrations in the overlying water. In half of the vertical profiles, the upper $10 \mathrm{~mm}$ of sediment contains as much chl $a$ as the overlying 1.25 to $2 \mathrm{~m}$ deep water column (Fig. 9). Resuspension under controlled conditions has shown that only 2 to $11 \%$ of the chl $a$ in the upper sediment is resuspended (Delgado et al. 1991, Sloth et al. 1996). However, these studies used sediment in which there was a well-developed algal mat, which can stabilize the sediment by excretion of extra-cellular organic compounds (Holland et al. 1974, Yallop et al. 1994) and retard resuspension. There was no surficial mat in any of the cores from San Antonio Bay, so resuspension might have involved more than the upper $6 \mathrm{~mm}$ described by Sloth et al. (1996): other studies have shown that the upper 3 to $5 \mathrm{~cm}$ of sediment may be involved (Jennes \& Duineveld 1985. Arfi et al. 1993). 
The measured concentrations of benthic chl a are therefore high enough to account for much of the observed variability in suspended chl a

The importance of resuspension in San Antonio Bay could be inferred from the high turbidity in the absence of any other data. Resuspension would also account for the tight coupling between productivity in the water column and grazing by the benthic meiofauna during this study (Montagna \& Yoon 1991). The probability that resuspension causes the short-term variability in the water column can be inferred directly from the correlation analyses and the predictive power of the productivity models and indirectly from the abundance and $P$-I responses of the benthic microalgae. None of the evidence is conclusive but taken together is strongly suggestive. Of 12 correlation analyses, 3 appeared to be consistent with resuspension and 3 appeared to be inconsistent (Table 3 ). However, the lack of a trend between changes in chl $a$ and turbidity does not preclude resuspension as the mechanism underlying short-term variability. Linear correlation does not account for the complex interactions that occur in an estuary, 4 of which are of particular importance. First, resuspension is correlated with the tidal velocity maximum (Baillie \& Welsh 1980, Litaker et al. 1993) and so is out of phase with tidal amplitude (and salinity) and shows a hysteresis between flooding and ebbing tides. Second, resuspension may be caused by wind-driven mixing (Gabrielson \& Lukatelich 1985 Pejrup 1986, Demers et al. 1987. Arfi et al. 1993) rather than tides. Wind speed tends to vary on a diel basis, being higher during the day than at night, so resuspension may be largely independent of tidally-driven changes in salinity. Third, microalgal cells, silt and sand have different characteristics of resuspension (and presumably settling) at a given flow velocity (de Jonge \& van der Bergs 1987, Delgado et al. 1991). Fourth, there may be a strong diel rhythm of grazing on suspended microalgae, superimposed on variations caused by advection and/or resuspension (Litaker et al. 1988, 1993) All of these effects will obscure simple, linear relationships between salinity, chl $a$ and turbidity.

A further indication that resuspension drives shortterm variability comes from the covariation between components of the composite parameter $M$ (i.e. $P_{\mathrm{m}}^{\mathrm{rhl}}$, $C h l$ and $k$ ). The observed variation in $M$ was less than expected on the assumption of independent changes in its components, indicating that the covariation of chl a and turbidity or $P_{\mathrm{m}}^{\mathrm{chl}}$ and turbidity outweighed covariation between chl a and $P_{\mathrm{m}}^{\mathrm{chl}}$. Resuspension would lead to both covariation of chl $a$ and turbidity and chl $a$ and $P_{\mathrm{m}}^{\mathrm{chl}}$, as the benthic assemblage had consistently lower light-saturated rates of photosynthesis than the suspended population (Fig 10). Covariation of $P_{m}^{c h l}$ and turbidity could be a secondary effect of resuspension if the increase in turbidity alleviated photoinhibition and allowed recovery of $P_{\mathrm{m}}^{\mathrm{chl}}$ Were this to occur, it would over-ride the relationship between changes in chl a and $P_{\mathrm{m}}^{\mathrm{chl}}$, even in the absence of covariation between chl $a$ and turbidity. The BZI model, which lacks any description of the $P$-I response, provides evidence for covariation between chl $a$ and turbidity: the predictive power of the $B Z I$ parameter was not reduced when it was based on a single observation of the chl a content in the euphotic zone rather than the average value through the day.

Last, the action of resuspension can be inferred from the abundance and $P-I$ responses of the benthic microalgae. The photosynthetic responses of the phytobenthos are inconsistent with those of an assemblage restricted to an aphotic or nearly aphotic environment. The photic zone did not extend to the sediment-water interface in 70 of 106 observations but, where it did, only the upper 0.7 to $1.0 \mathrm{~mm}$ of the sediment would be illuminated. There was no relationship between $p_{m}^{\mathrm{chl}}$ and the mean irradiance in the sediment and the relatively high values of $P_{\mathrm{m}}^{\mathrm{chl}}$ are atypical of low-light acclimated or relict populations of microalgae. Instead, variations in $P_{\mathrm{m}}^{\mathrm{chl}}$ in both the dimly lit 0 to $1 \mathrm{~mm}$ and aphotic 2 to $3 \mathrm{~mm}$ strata were strongly correlated with those in the suspended population, suggesting that both have similar light histories. The pattern held both for the absolute values of $P_{\mathrm{m}}^{\mathrm{ch}}$ and for the deviations from the trends predicted by temperature (Fig. 10)

The decline in $P_{\mathrm{m}}^{\mathrm{chl}}$ between the 0 to 1 and 2 to $3 \mathrm{~mm}$ assemblages (Fig. 10) may be due to less frequent exposure to light of the deeper assemblage, as argued previously (MacIntyre \& Cullen 1995). It might also be due to an artifact introduced by fluorometric determination of chl $a$, in spite of the nominal correction for degradation products. Where fluorometric assays have been compared with HPLC in benthic samples, fluorometry may overestimate chl a concentration (Daemen 1986, Riaux-Gobin et al. 1987) although it does not always do so (Plante-Cuny et al. 1993, Sun et al. 1994, MacIntyre et al. 1996). Where it occurs, the overestimate is likely due to the presence of the degradation product chlorophyllide, which has optical properties identical to those of chlorophyll (Holt \& Jacobs 1954) and is therefore detected as chlorophyll by fluorometry spectrophotometry. If there were an increase in chlorophyllide concentrations in the uppermost sediment in San Antonio Bay, $P_{\mathrm{m}}^{\mathrm{chl}}$ would be underestimated in the deeper assemblages

Although there is no direct evidence for resuspension, we argue that there is strong circumstantial evidence. The compensatory nature of short-term changes in the characteristics of the water column has an important consequence for monitoring productivity: 
reasonable estimates of productivity can be obtained without a full description of the short-term variability.

\section{Estimating daily productivity}

Studies in other estuaries have shown that a high degree of variability in chl a and attenuation does not translate to an equally high degree of variability in productivity (Demers et al. 1987. Cloern et al. 1989, Powell et al. 1989, Litaker et al. 1993). This is also the case in San Antonio Bay. The practical consequence is that reasonable estimates of daily productivity can probably be obtained from single measurements of chl $a$ and turbidity, particularly when these are complemented by a description of $P-I$ response, and continuous measurement of irradiance. Monitoring programs frequently rely on limited discrete sampling of water column parameters, which may be complemented by continuous recording of such parameters such as irradiance and temperature. The coherence in the variability in chl $a$, turbidity and $P_{m}^{\mathrm{ch}}$ translates into a reduced need to sample the water column in order to get accurate descriptions of daily productivity

One of the simplest models for estimating daily productivity is the BZI model proposed by Cole \& Cloern (1984). The empirical factor relating daily productivity to the $B Z I$ parameter (i.e. the slope of the regression) was not significantly different whether the relationship was determined from the full variability in chl a and $z_{\mathrm{eu}}$ or from the midday values only. The slope was 0.67 to 0.88 and comparable to values determined empirically in other estuaries, which range between 0.36 and 1.8 (Cole \& Cloern 1987, Keller 1988, Cole 1989, Boyer et al. 1993). The coefficient of determination $\left(R^{2}=0.72\right)$ was in the mid-range of the coefficients from other studies, 0.42 to 0.94 (Cole \& Cloern 1984, 1987, Harding et al. 1986, Pennock \& Sharp 1986, Keller 1988, Cole 1989, Mallin et al. 1991, Boyer et al. 1993).

Although $72 \%$ of the variability in daily productivity can be accounted for by the BZI model, a better estimate can be made by supplementing the data with the $P$ - $I$ response of the suspended assemblage. In the 3 models discussed here, a single $P$ - $I$ curve is used to generate either one or more estimates of productivity that are extrapolated to a daily rate. In the first, Model 1 (Marshall et al. 1971), productivity at midday is multiplied by day-length to yield an estimate of daily productivity. An implicit assumption is that productivity is independent of incident irradiance, which is not the case. As productivity at midday was generally higher than at other times of the day, Model 1 tended to overestimate daily productivity (slope $=1.35$ ), although it could describe more of the variability in $\prod_{\text {day }}\left(\mathrm{R}^{2}=0.88\right)$ than the BZI model. Model 2 (Leach
1970) differs from Model 1 in that it relates areal productivity to incident irradiance, assuming that the relationship is linear (but see plots of $\prod_{I(t)}$ vs $I_{0}$ in Fig 5). The error in each estimate depends on the degree of curvature of the true relationship. Model 2 gives a good estimate where there is little curvature (i.e. where $I_{k}$ is high and/or there is little or no fall-off in the $P$-I curve at high irradiance). It underestimates daily productivity where the average daily irradiance is lower than irradiance at midday and would overestimate daily productivity if the mean irradiance were higher. On average, it underestimated daily productivity by $12 \%$ (slope $=0.88, R^{2}=0.88$ ). Model 3 differs from Model 2 in that it corrects for the non-linearity of the $\prod_{l(t)}$ vs $I_{0}$ curve. It gave the closest estimate of daily productivity of the 3 models (slope $=1.06, \mathrm{R}^{2}=0.93$ ).

Although based on only 10 observations, this analysis suggests that good estimates of daily productivity can be made without accounting for the high withinday variability in turbidity and microalgal abundance and $P-I$ response. Incorporating the $P$-I response into the estimate of daily productivity improves the accuracy of the estimate and frees it from its reliance on an empirically-derived conversion factor, which may vary between sites, between seasons or with the nutrient status of the assemblage (Pennock \& Sharp 1986, Cole \& Cloern 1987). Because differences in $\prod_{\text {noon }}$ on consecutive days approached month-to-month variability in San Antonio Bay, the optimal use of limited resources would minimize within-day sampling and would focus on between-day variability. Models 2 and 3 give good predictions of $\prod_{d a y}$, with average errors of 28 and $27 \%$, respectively. Between-day variations in $\prod_{\text {noon }}$ were $13 \%, 52 \%, 44 \%$ and $21 \%$ (Fig. 5). It would be a better use of resources to characterize betweenday variability rather than reduce the error on withinday variability on a reduced set of samples.

\section{Summary}

The waters of San Antonio Bay were both turbid and productive. The high degree of short-term (hours) variability in the physical and biological characteristics of the water column were likely due to resuspension of the benthos, which contained an abundant assemblage of photosynthetically-competent microalgae. Resuspension could account for the predominant covariance between chl a and turbidity and between turbidity and light-saturated rates of photosynthesis, $P_{\mathrm{m}}^{c h}$. The high short-term variability in the water column did not result in comparable variability in productivity because of the compensatory increase in microalgal biomass and recovery of $P_{\mathrm{m}}^{\mathrm{chl}}$ from photoinhibition as turbidity increased. As a result, estimates of daily 
productivity based on single observations of suspended chl $a$, light attenuation and $P$ - I response could predict daily productivity with reasonable fidelity. The high degree of between-day variability indicates that the optimal use of resources would focus on betweenday rather than within-day variability.

Acknowledgements. We thank Rob Lane, Joe Dirnberger, Jake Garrett, Mark Westerman, Rick Kalke, Paul Montagna and Capt. John Turany of the RV 'Katy' for help in sampling. Richard Geider and 3 anonymous reviewers provided valuable criticism of the manuscript. This work was supported by the Texas Water Development Board Interagency Contract IAC (86-87) 0757 and NSERC funding to J.J.C. and by NSF Grant OCE-9301768 to Richard Geider.

\section{LITERATURE CITED}

Anderson FE (1976) Rapid settling rates observed in sediments resuspended by boat waves over a tidal flat. Neth $J$ Sea Res 10:44-58

Arf $R_{1}$ Guiral D, Bouvy M (1993) Wind induced resuspension in a shallow tropical lagoon. Estuar Coast Shelf Sci 36: $587-604$

Arsalane W, Rousseau B, Duval JC (1994) Influence of the pool size of the xanthophyll cycle on the effects of light stress in a diatom: competition between photoprolection and photoinhibition. Biochem Photobiol 60:237-243

Baillie PW, Welsh BL (1980) The effect of tidal resuspension on the distribution of intertidal epipelic algae in an estuary. Estuar Coast Shelf Sci 10:165-180

Bevington PR (1969) Data reduction and error analysis for the physical sciences, McGraw Hill, Hightstown, NJ

Boyer JN, Christian RR. Stanley DW (1993) Patterns of phytoplankton promary productivity in the Neuse River estuary, North Carolma, USA. Mar Ecol Prog Ser 97:287-297

Cloern JE (1987) Turbidity as a control on phytoplankton biomass and productivity in estuaries. Cont Shelf Res 7 : $1367-1381$

Cloern JE, Powell TM, Huzzey LM (1989) Spatial and temporal variability in south San Francisco Bay (USA) II. Temporal changes in salinity, suspended sediments, and phytoplankton biomass and productivity over tidal time scales. Estuar Coast Shelf Sci 28:599-613

Cole B (1989) Temporal patterns of phytoplankton production in Tomales Bay, California, U.S.A. Estuar Coast Shelf ScI 28:103-115

Cole B, Cloern JE (1984) Significance of biomass and light availability to phytoplankton productivity in San Francisco Bay. Mar Ecol Prog Ser 17:15-24

Cole B. Cloern JE (1987) An empirical model for estimating phytoplankton productivity in estuaries. Mar Ecol Prog Ser 36:299-305

Cullen JJ, Lewis MR (1988) The kinetıcs of algal photoadaptation in the context of vertical mixing. J Plankton Res 10: $1039-1063$

Cullen JJ, Lewis MR, Davis CO, Barber RT (1992) Photosynthetic characteristics and estumated growth rates indicate grazing is the proximate control of primary production in the equatorial Pacific. J Geophys Res 97:639-654

Cullen JJ, Yentsch CM. Cucci TL, MacIntyre HL (1988) Autofluorescence and other optical properties as tools in biological oceanography. SPIE 925:149-156

Daemen EAMJ (1986) Comparison of methods for the deter- mination of chlorophyll in estuarine sediments. Neth J Sea Res 20:21-28

Davis RF (1986) Measurement of primary production in turbid waters. MSc thesis, University of Texas at Austin

Day JW. Hall CAS, Kemp WM, Yánez-Arancibia A (1989) Estuarine ecology. John Wiley \& Sons, Inc, New York

de Jonge VN, van Beusekom JEE (1992) Contribution of resuspended microphytobenthos to total phytoplankton in the Ems Estuary and its possible role for grazers. Neth J Sea Res 30:91-105

de Jonge VN, van den Bergs J (1987) Experments on the resuspension of estuarine sediments containing benthic diatoms. Estuar Coast Shelf Sci 24:725-740

Delgado $M$, de Jonge VN, Peletier H (1991) Expcriments on resuspension of natural microphytobenthos populations. Mar Biol 108:321-328

Demers S, Roy S, Gagnon R, Vignault C (1991) Rapid lightinduced changes in cell fluorescence and in xanthophyllcycle pigments of Alexandrium excavatum (Dinophyceae) and Thalassrosira pseudonana (Bacillariophyceae): a photo-protection mechanism. Mar Ecol Prog Ser 76: $185-193$

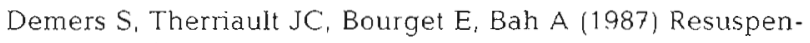
sion in the shallow sublittoral zone of a macrotidal estuarine environment: wind influence. Limnol Oceanogr 32: $327-339$

Dustan P, Pinckney JLJ (1989) Tidally induced estuarine phytoplankton patchiness. Limnol Oceanogr 34:410-419

Elser JJ, Kmmel BL (1985) Photoinhibition of temperate lake phytoplankton by near-surface irradiance: evidence from vertical profiles and field experiments. J Phycol 21 419-427

Eppley RW (1972) Temperature and phytoplankton growth in the sea. Fish Bull 70:1063-1085

Gabrielson JO, Lukatelich RJ (1985) Wind-related resuspension of sediments in the Peel-Harvey estuarine system. Estuar Coast Shelf Sci 20:135-145

Garrad P. Hey RD (1987) Boat traffic, sediment resuspension and turbidity in a broadland river. J Hydrology 95: 289-297

Geider RJ (1993) Quantitative phytoplankton physiology: implications for primary production and phytoplankton growth. ICES Mar Sci Symp 194:52-62

Glibert PM, Dennett MR, Goldman JC (1985) Inorganic carbon uptake by phytoplankton in Vineyard Sound, Massachusetts. I. Measurements of the photosynthesis-irradiance response of winter and early-spring assemblages. J Exp Mar Biol Ecol 85:21-36

Guillard RRL (1975) Culture of phytoplankton for feeding marine invertebrates. In: Smith WL, Chanley $\mathrm{MH}$ (eds) Culture of marine invertebrate animals. Plenum Publishing Co, New York, p 108-132

Harding LW, Fisher TR, Tyler MA (1987) Adaptive responses of photosynthesis in phytoplankton: specificity to timescale of change in light Biol Oceanogr 4:403-437

Harding LW, Prezelin BB, Sweeney BM, Cox JL (1982) Diel osrillations of the photosynthesis-irradiance (PI) relationship in natural assemblages of phytoplankton. Mar Biol 67:167-178

Harding LWJ, Meeson BW, Fisher TRJ (1986) Phytoplankton production in two east coast estuaries: photosynthesislight functions and patterns of carbon assimilation in Chesapeake and Delaware Bays. Estuar Coast Shelf Sci 23:773-806

Harns GP, Piccinin BB (19F7) Photosynthesis by natural populations of phytoplankton. Arch Hydrobiol 80:405-457

Harrison WG. Platt T (1980) Variations in assimilation number 
of coastal marine phytoplankton: effects of environmental co-variates. J Plankton Res 2:249-260

Henley WJ (1993) Medsurement and interpretation of photosynthetic light-response curves in algae in the context of photoinhibition and diel changes. J Phycol 29:729-739

Holland AF, Zingmark RG, Dean JM (1974) Quantitative evıdence concerning the stabilization of sediments by marine benthic diatoms. Mar Biol 27:191-196

Holm-Hansen O (1978) Chlorophyll a determination: improvements in methodology. Oikos 30:438-447

Holt A.S, Jacobs EE (1954) Spectroscopy of plant pigments. 1 Ethyl chlorophyllides $A$ and $B$ and their phaeophorbides. Am J Bot 41:710-722

Ibelings BW, Kroon BMA, Mur LR (1994) Acclımation of photosystem il in a cyanobacterium and a eukaryotic green alga to high and fluctuating photosynthetic photon flux densities, simulating light regimes induced by mixing in lakes. New Phytol 128:407-424

Jennes MI, Duineveld GCA (1985) Effects of tidal currents on chlorophyll a content of sandy sediments in the southern North Sea. Mar Ecol Prog Ser 21:283-287

Joint IR, Gee JM, Warwick RM (1982) Determination of finescale vertical distribution of microbes and merofauna in an intertidal sediment. Mar Biol 72:157-164

Kana TM (1992) Relationship between photosynthetic oxygen cycling and carbon assimilation in Symechococcus WH7803 (Cyanophyta). J Phycol 28:304-308

Keller AA (1988) Estimating phytoplankton productivity from light dvailability and biomass in the MERL mesocosms and Narragansett Bay. Mar Ecol Prog Ser 45:159-168

Keller MD. Selvin RC, Claus W, Guillard RRL (1987) Media for the culture of oceanic ultraphytoplankton. J Phycol 23: $633-638$

Kiefer DA (1973) Fluorescence properties of natural phytoplankton assemblages. Mar Biol 22:263-269

Kirk JTO (1985) Effects of suspensoids on penetration of solar radiation in aquatic ecosystems. Hydrobiologia 125 : $195-208$

Kromkamp J, Limbeek M (1993) Effect of short-term variation in irradiance on light harvesting and photosynthesis of the marine diatom Skeletonema costatum: a laboratory study simulating vertical mixing. J Gen Microbiol 139 : $2277-2284$

Kroon BMA, Burger-Wiersma T, Visser P, Mur LR (1992) The effect of dynamic light regimes on Chlorella. I. Minimum quantum requirement and photosynthesis-irradiance parameters. Hydrobiologia 238:79-88

Kühl, M, Jorgensen BB (1994) The light field in microbenthic communities: radiance distribution and the microscale optics of sandy coastal sediments. Limnol Oceanogr 39 : $1368-1399$

Leach JH (1970) Epibenthic algal production in an intertıdal mudflat. Limnol Oceanogr 15:514-521

Levasseur M, Therriault J-C, Legendre L (1983) Tidal currents, winds and the morphology of phytoplankton spatral structure. J Mar Res 41:655-672

Leverenz JW, Falk S, Pilstrom C-M, Samuelsson G (1990) The effects of photoinhibition on the photosynthetic lightresponse curve of green plant cells (Chlammydomonas reinhardtii). Planta 182:161-168

Lewis MR, Smith JC (1983) A small-volume, short-incubationtime method for measurement of photosynthesis as a function of incident uradiance. Mar Ecol Prog Ser 13:99-102

Litaker W. Duke CS, Kenney BE, Ramus J (1988) Diel chl a and phaeopigment cycles in a shallow tidal estuary: potential role of microzooplankton grazing. Mar Ecol Prog Ser 47:259-270
Litaker W, Duke CS, Kenney BE, Ramus J (1993) Short-term variability and phytoplankton abundance in a shallow tidal estuary. II. Spring and fall. Mar Ecol Prog Ser 94: $141-154$

Lohrenz SE, Fahnenstiel GL, Redalje DG (1994) Spatial and temporal variations of photosynthetıc parameters in relatron to environmental conditions in coastal waters of the Northern Gulf of Mexico. Estuaries 17:779-795

MacIntyre HL, Cullen JJ (1995) Fine-scale vertical resolution of chlorophyll and photosynthetic parameters in shallowwater benthos. Mar Ecol Prog Ser 122:227-237

MacIntyre HL, Geider RJ, Miller DC (1996) Microphytobenthos: the ecological role of the 'secret garden' of unvegetated, shallow-water marine habitats. I. Distribution, abundance and primary production. Estuaries 19:186-201

Macintyre S (1993) Vertical mixing in a shallow, eutrophic lake: possible consequences for the light climate of phytoplankton. Limnol Oceanogr 38:798-817

Mallin MA, Paerl HW (1992) Effects of variable irradiance on phytoplankton productivity in shallow water. Limnol Oceanogr 37:54-63

Mallin MA, Paerl HW, Rudek J (1991) Seasonal phytoplankton composition, productivity and biomass in the Neuse River estuary, South Carolina. Estuar Coast Shelf Sci 32: $609-623$

Malone TC (1977) Light-saturated photosynthesis by phytoplankton size fractions in the New York Bight, USA. Mar Biol 42:281-292

Malone TC. Neale PJ (1981) Parameters of light-dependent photosynthesis for phytoplankton size fractions in temperate estuarine and coastal environments. Mar Biol 61 $289-297$

Marra J (1978a) Effect of short-term variations in light intensity on photosynthesis of a marine phytoplankter: a laboratory simulation study. Mar Biol 46:191-202

Marra J (1978b) Phytoplankton photosynthetic response to vertical movement in a mixed layer. Mar Biol 46:203-208

Marshall N, Oviatt CA, Skauen DM (1971) Productivity of the benthic microflora of shoal estuarine environments in southern New England. Int Rev Gesamten Hydrobial 56 947-956

Montagna PA, Yoon WB (1991) The effect of freshwater inflow on meiofaunal consumption of sediment bacteria and microphytobenthos in San Antonio Bay, Texas, USA Estuar Coast Shelf Sci 33:529-547

Neale PJ, Cullen JJ, Yentsch CM (1989) Bio-optical inferences from chlorophyll a fluorescence: what kind of fluorescence is measured in flow cytometry. Limnol Oceanogr $34: 1739-1748$

Neale PJ, Richerson PJ (1987) Photoinhibition and the diurnal variation of phytoplankton photosynthesis-1. Development of a photosynthesis-rradiance model from studies of in situ responses. J Plankton Res 9:167-193

Neale PJ, Talling JF, Heaney SI, Reynolds CS, Lund JWG (1991) Long time series from the English Lake District: irradiance-dependent phytoplankton dynamics during the spring maxımum. Limnol Oceanogr 36:751-760

Olarzola M. Yamamoto HY (1994) Short-term response of the diadinoxanthin cycle and fluorescence yield to high irradiance in Chaetoceros muelleri (Bacillariophyceae) J Phycol 30:606-612

Pejrup M (1986) Parameters affecting fine-grained suspended sediment concentrations in a shallow micro-tidal estuary, Ho Bugt, Denmark. Estuar Coast Shelf Sci 22:241-254

Pennock JR, Sharp JH (1986) Phytoplankton production in the Delaware Estuary: temporal and spatial variability. Mar Ecol Prog Ser 34:143-155 
Phinney DA, Yentsch CS (1985) A novel phytoplankton chlorophyll technique: toward automated analysis. J Plankton Res 7:633-642

Plante-Cuny M, Barranguet C, Bonn D, Grenz C (1993) Does chlorophyllide a reduce reliability of chlorophyll a measurements in marine coastal sediments? Aquat Sci 55: $19-30$

Platt T, Gallegos CL, Harrison WG (1980) Photoinhibition of photosynthesis in natural assemblages of marine phytoplankton. J Mar Res 38:687-701

Platt T, Sathyendranath S, Ravindran P (1990) Primary production by phytoplankton: analytic solutions for daily rates per unit area of water surface. Proc R Soc Lond 241:101-111

Post AF, Dubinsky Z, Wyman K, Falkowski PG (1984) Kunetics of light-intensity adaptation in a marine planktonic diatom. Mar Biol 83:231-238

Powell TM, Cloern JE, Huzzey LM (1989) Spatial and temporal variability in south San Francisco Bay (USA) I. Horizontal distributions of salinity, suspended sediments, and phytoplankton biomass and productivity. Estuar Coast Shelf Sci 28:583-597

Ralston KL, Jennrich RI (1978) DUD, a derivative-free algorithm for nonlinear least squares. Technometrics 20:7-14

Randall JM, Day JW (1987) Effects of nver discharge and vertical circulation on aquatic primary production in a turbid Louisiana (USA) estuary. Neth J Sea Res 21:231-242

Riaux-Gobin C, Llewellyn CA, Klein B (1987) Microphytobenthos from two subtidal sediments from North Brittany. II Variations of pigment compositions and concentrations determined by HPLC and conventional techniques. Mar Ecol Prog Ser 40:275-283

Shaffer GP, Sullivan MJ (1988) Water column productivity attributable to displaced benthuc diatoms in well-mixed shallow estuaries. J Phycol 24:132-140

Sinclair M. Chanut JP, El-Sabh M (1980) Phytoplankton distributions observed during a $3 \frac{1}{2}$ days fixed-station in the lower St. Lawrence Estuary. Hydrobiologia 75:129-147

Sloth NP, Riemann B, Nielsen LP, Blackburn TH (1996) Resilience of pelagic and benthic microbial communities

This article was submitted to the editor to sediment resuspension in a coastal ecosvstem, Knebel Vig, Denmark. Estuar Coast Shelf Sci 42:40j 115

Sullivan MJ, Moncrieff CA (1988) Primary production of edaphic algal communities in a Mississippi salt marsh. J Phycol 24:49-58

Sun MY, Aller RC, Lee C (1994) Spatial and temporal distributions of sedimentary chloropigments as benthic processes in Long Island Sound. J Mar Res 52:149-176

Talling JF (1957) The phytoplankton population as a compound photosynthetic unit. New Phytol 56:133-149

Vincent WF, Bertrand N, Frenette JJ (1994) Photoadaptation to intermittent light across the St. Lawrence freshwatersaltwater transition zone. Mar Ecol Prog Ser 110:283-292

Vincent WF, Neale PJ, Richerson PJ (1984) Photoinhubition: algal responses to bright light during diel stratification and mixing in a tropical alpine lake. J Phycol 20:201-211

Walker TA (1981) Dependence of phytoplankton chlorophyll on bottom resuspension in Cleveland Bay, northern Queensland. Aust J Mar Freshwat Res 32:981-986

Walmsley RD, Butty M, Van Der Peipen H, Grobler D (1980) Light penetration and the interrelationships between optical parameters in a turbid subtropical impoundment. Hydobiologia 70:145-157

Whitledge TE (1989) Data synthesis and analysis. Nitrogen processes study (NIPS): Nutrient distributions and dynamics in Lavaca, San Antonio and Nueces/Corpus Christi Bays in relation to freshwater inflow. Part II: Hydrography, nutrient and chlorophyll data tables. University of Texas Marine Science Institute Technical Report No. TR/89-007 University of Texas, Port Aransas

Yallop ML, de Winder B, Paterson DM, Stal LJ (1994) Comparative structure, primary production and biogenic stabilization of cohesive and non-cohesive marine sediments inhabited by microphytobenthos. Estuar Coast Shelf Sci 39:565-582

Zimmerman RC, SooHoo JB, Kremer JN, D'Argenı DZ (1987) Evaluation of variance approximation techniques for non-linear photosynthesis-irradiance models. Mar Biol 95:209-215

Manuscript first received: January 31, 1995

Revised version accepted: September 11, 1996 